\title{
Vaccine effectiveness in preventing laboratory- confirmed influenza in primary care patients in a season of co-circulation of influenza A(H1N1)pdm09, B and drifted A(H3N2), I-MOVE Multicentre Case-Control Study, Europe 2014/15
}

M Valenciano ${ }^{12}$, E Kissling ${ }^{12}$, A Reuss ${ }^{3}$, C Rizzo ${ }^{4}$, A Gherasim 5 , JK Horváth 6 , L Domegan 7 , D Pitigoi ${ }^{8}$, A Machado 9 , IA

Paradowska-Stankiewicz ${ }^{10}$, A Bella ${ }^{11}$, A Larrauri ${ }^{12}$, A Ferenczi ${ }^{13}$, Joan O'Donell ${ }^{7}$, M Lazar $^{14}$, P Pechirra $^{15}$, MR Korczyńska ${ }^{10}$, F

Pozo ${ }^{16}$, A Moren ${ }^{1}$, on behalf of the I-MOVE multicentre case-control team ${ }^{17}$

1. Epidemiology Department, EpiConcept, Paris, France

2. These authors contributed equally to this manuscript

3. Department for Infectious Disease Epidemiology Respiratory Infections Unit, Robert Koch Institute, Berlin, Germany

4. Istituto Superiore di Sanità, Rome, Italy

5. National Centre of Epidemiology, Institute of Health Carlos III, Madrid, Spain

6. Department of Public Health, Strategic Planning and Epidemiology, Office of the Chief Medical Officer, Budapest, Hungary

7. Health Service Executive-Health Protection Surveillance Centre, Dublin, Ireland

8. University of Medicine and Pharmacy 'Carol Davila', 'Institutul National de Cercetare-Dezvoltare pentru Microbiologie si Immunologie 'Cantacuzino', Bucharest, Romania

9. Department of Epidemiology, National Institute of Health Dr. Ricardo Jorge, Lisbon, Portugal

10. Polish National Institute of Public Health, Warsaw, Poland

11. Istituto Superiore di Sanità, Rome, Italy

12. National Centre of Epidemiology/ CIBER Epidemiología y Salud Pública (CIBERESP), Institute of Health Carlos III, Madrid, Spain

13. Department of Public Health, Strategic Planning and Epidemiology, Office of the Chief Medical Officer, Budapest, Hungary 14. 'Institutul National de Cercetare-Dezvoltare pentru Microbiologie si Immunologie 'Cantacuzino', Bucharest Romania

15. Department of Infectious Diseases, National Institute of Health Dr. Ricardo Jorge, Lisbon, Portugal

16. National Centre for Microbiology, National Influenza Centre Institute of Health Carlos III, Madrid, Spain

17. The members of the team are listed at the end of the article

Correspondence: Marta Valenciano (m.valenciano@epiconcept.fr)

Citation style for this article:

Valenciano M, Kissling E, Reuss A, Rizzo C, Gherasim A, Horváth J, Domegan L, Pitigoi D, Machado A, Paradowska-Stankiewicz I, Bella A, Larrauri A, Ferenczi A, Joan O'Donell, Lazar M, Pechirra P, Korczyńska M, Pozo F, Moren A, on behalf of the I-MOVE multicentre case-control team. Vaccine effectiveness in preventing laboratory-confirmed influenza in primary care patients in a season of co-circulation of influenza $A\left(\mathrm{H}_{1} \mathrm{~N}_{1}\right)$ pdmo9, $B$ and drifted $A\left(\mathrm{H}_{3} \mathrm{~N}_{2}\right)$, I-MOVE Multicentre CaseControl Study, Europe 2014/15. Euro Surveill. 2016;21(7):pii=30139. DOI: http://dx.doi.org/10.2807/1560-7917.ES.2016.21.7.30139

Article submitted on 12 October 2015 / accepted on 25 November 2015 / published on 18 February 2016

Influenza $\mathrm{A}\left(\mathrm{H}_{3} \mathrm{~N}_{2}\right), \mathrm{A}\left(\mathrm{H}_{1} \mathrm{~N}_{1}\right) \mathrm{pdmog}$ and $\mathrm{B}$ viruses cocirculated in Europe in 2014/15. We undertook a multicentre case-control study in eight European countries to measure 2014/15 influenza vaccine effectiveness (VE) against medically-attended influenza-like illness (ILI) laboratory-confirmed as influenza. General practitioners swabbed all or a systematic sample of ILI patients. We compared the odds of vaccination of ILI influenza positive patients to negative patients. We calculated adjusted VE by influenza type/subtype, and age group. Among 6,579 ILI patients included, 1,828 were $A\left(\mathrm{H}_{3} \mathrm{~N}_{2}\right), 539 \mathrm{~A}\left(\mathrm{H}_{1} \mathrm{~N}_{1}\right)$ pdmog and $1,038 \mathrm{~B}$. VE against $A\left(\mathrm{H}_{3} \mathrm{~N}_{2}\right)$ was $14.4 \%$ (95\% confidence interval (Cl): -6.3 to 31.0$)$ overall, $20.7 \%(95 \% \mathrm{Cl}:-22.3$ to $48.5), 10.9 \%(95 \% \mathrm{Cl}-30.8$ to 39.3$)$ and $15.8 \%(95 \%$ $\mathrm{Cl}:-20.2$ to 41.0$)$ among those aged $0-14,15-59$ and $\geq 60$ years, respectively. VE against $A\left(\mathrm{H}_{1} \mathrm{~N}_{1}\right)$ pdmog was $54.2 \%$ ( $95 \% \mathrm{Cl}: 31.2$ to 69.6 ) overall, $73.1 \%$ ( $95 \% \mathrm{Cl}: 39.6$ to 88.1 ), $59.7 \%$ (95\%Cl: 10.9 to 81.8 ), and $22.4 \%$ (95\%Cl: -44.4 to 58.4 ) among those aged $0-14$,
15-59 and $\geq 60$ years respectively. VE against B was $48.0 \%$ (95\% Cl: 28.9 to 61.9$)$ overall, $62.1 \%(95 \% \mathrm{Cl}$ : 14.9 to 83.1 ), $41.4 \%$ (95\% 6.2 to 63.4 ) and $50.4 \%$ (95\% $\%$ : 14.6 to 71.2 ) among those aged $0-14,15-59$ and $\geq 60$ years respectively. VE against $A\left(\mathrm{H}_{1} \mathrm{~N}_{1}\right)$ pdmo9 and $B$ was moderate. The low VE against $A\left(\mathrm{H}_{3} \mathrm{~N}_{2}\right)$ is consistent with the reported mismatch between circulating and vaccine strains.

\section{Introduction}

In February 2014 each year, the World Health Organization (WHO) provides recommendations for the composition of the northern hemisphere vaccines, based on information from the WHO Global Influenza Surveillance and Response System. In 2014, the WHO vaccine strain selection committee recommended that the 2014/15 northern hemisphere influenza vaccine should include the same components as in 2013/14: an A/California/7/2009 $\left(\mathrm{H}_{1} \mathrm{~N}_{1}\right)$ pdmog-like 


\section{FIGURE 1}

Flowchart of data exclusion for pooled analysis, I-MOVE multicentre case-control study, Europe, influenza season 2014/15 (week 41/2014-week 19/2015)

\section{Number of records received for pooled analysis}

\section{7,992}

\section{Records excluded}

- Patients with contraindications against vaccination $(n=0)$

- Patients administered antivirals prior to swabbing $(n=8)$

- Patients with missing lab results $(n=10)$

- Patients with missing onset date $(n=236)$

- With date of onset of symptoms $\ll 15$ days after begin of vaccination campaign $(n=3)$

- Not meeting the EU ILI case definition $(n=859)$ or EU ILI status unknown $(n=98)$

- With interval between onset of symptoms and swabbing $>7$ days $(n=137)$

- Excluding patients presenting before ISO week of any influenza case and after ISO week of last influenza case after which there are two consecutive weeks of no cases (weeks of symptom onset, by country) $(n=62)$

$$
\mathrm{N}=6,579 \text {; cases of any influenza: } 3,437 \text {; controls: } 3,142
$$

\begin{tabular}{|c|c|c|}
\hline Influenza $\mathrm{A}\left(\mathrm{H}_{3} \mathrm{~N}_{2}\right)$ analysis & Influenza $\mathrm{A}\left(\mathrm{H}_{1} \mathrm{~N}_{1}\right)$ pdmog analysis & Influenza B analysis \\
\hline \multicolumn{3}{|c|}{ - Dropping influenza-positive records of different type/subtype } \\
\hline$(n=1,608)$ & $(n=2,896)$ & $(n=2,397)$ \\
\hline \multicolumn{3}{|c|}{$\begin{array}{l}\text { - Excluding patients presenting before ISO week of first type/subtype-specific influenza case and after ISO week } \\
\text { of last type/subtype-specific influenza case after which there are two consecutive weeks of no cases (weeks of } \\
\text { symptom onset, by country) }\end{array}$} \\
\hline$(n=151)$ & $(n=531)$ & $(n=180)$ \\
\hline $\begin{array}{l}\quad 4,820 \\
\text { Cases: } 1,828^{\text {a }} \\
\text { Controls: } 2,992\end{array}$ & $\begin{array}{l}3,152 \\
\text { Cases: } 539^{b} \\
\text { Controls: } 2,613\end{array}$ & $\begin{array}{l}\text { 4,002 } \\
\text { Cases: } 1,038^{\mathrm{a}, \mathrm{b}} \\
\text { Controls: } 2,964\end{array}$ \\
\hline
\end{tabular}

\section{Dropping records with missing data for complete case analysis}

\begin{tabular}{|c|c|c|}
\hline Influenza $\mathrm{A}\left(\mathrm{H}_{3} \mathrm{~N}_{2}\right)$ analysis & Influenza $\mathrm{A}\left(\mathrm{H}_{1} \mathrm{~N}_{1}\right)$ pdmog analysis & Influenza B analysis \\
\hline \multicolumn{3}{|c|}{ - Persons with missing 2014/15 influenza vaccination status or date } \\
\hline$(n=217)$ & $(n=153)$ & $(n=186)$ \\
\hline \multicolumn{3}{|c|}{ - Persons with missing information on age, sex or chronic disease } \\
\hline$(n=112)$ & $(n=79)$ & $(n=86)$ \\
\hline $\begin{array}{c}4,491 \\
{\text { Cases: } 1,723^{d}}^{\text {Controls } 2,768}\end{array}$ & $\begin{array}{c}\text { 2,920 } \\
\text { Cases: } 515^{\mathrm{e}} \\
\text { Controls } 2,405\end{array}$ & $\begin{array}{l}\quad 3,730 \\
\text { Cases: } 1,001^{\mathrm{d}, \mathrm{e}} \\
\text { Controls } 2,729\end{array}$ \\
\hline
\end{tabular}

\section{Records with missing vaccination brand for vaccine group analysis}

\begin{tabular}{|c|}
\hline $\begin{array}{c}\text { Influenza } \mathbf{A}\left(\mathrm{H}_{3} \mathrm{~N}_{2}\right) \\
(\mathrm{n}=82)\end{array}$ \\
\hline 4,409 \\
${\text { Cases: } 1,693^{\mathrm{d}}}^{\mathrm{d}}$ ansis \\
Controls: 2,716 \\
\hline
\end{tabular}

\begin{tabular}{|c|}
\hline $\begin{array}{c}\text { Influenza } \mathbf{A}\left(\mathrm{H}_{\mathbf{1}} \mathrm{N}_{\mathbf{1}}\right) \text { pdmog analysis } \\
(\mathrm{n}=53)\end{array}$ \\
\hline 2,867 \\
Cases: $508^{\mathrm{e}}$ \\
Controls: 2,359 \\
\hline
\end{tabular}

\begin{tabular}{|c|}
\hline $\begin{array}{c}\text { Influenza B analysis } \\
(\mathrm{n}=68)\end{array}$ \\
\hline 3,662 \\
Cases: $987^{\mathrm{d}, \mathrm{e}}$ \\
Controls: 2,675
\end{tabular}

EU: European Union; ILI: influenza-like illness; I-MOVE: Influenza Monitoring Vaccine Effectiveness in Europe; ISO: International Organization for Standardization.

a Includes 15 influenza $B+A\left(\mathrm{H}_{3} \mathrm{~N}_{2}\right)$ co-infections.

${ }^{b}$ Includes 8 influenza $B+A\left(\mathrm{H}_{1} \mathrm{~N}_{1}\right)$ pdmog co-infections.

${ }^{c}$ Includes 3 influenza $B+A\left(\mathrm{H}_{3} \mathrm{~N}_{2}\right)$ pdmo9, and $7 \mathrm{~A}\left(\mathrm{H}_{1} \mathrm{~N}_{1}\right)$ pdmo9 $+\mathrm{A}\left(\mathrm{H}_{3} \mathrm{~N}_{2}\right)$ co-infections.

${ }^{d}$ Includes 14 influenza $B+A\left(\mathrm{H}_{3} \mathrm{~N}_{2}\right)$ pdmog co-infections.

e Includes 7 influenza $\mathrm{B}+\mathrm{A}\left(\mathrm{H}_{1} \mathrm{~N}_{1}\right)$ pdmog co-infections. 


\section{FIGURE 2}

Number of influenza-like illness reports by case status and week of symptom onset, all influenza, target groups for vaccination, I-MOVE multicentre case-control study, Europe, influenza season 2014/15 (week 41/2014-week 19/2015) $\left(\mathrm{n}=6,524^{\mathrm{a}}\right)$

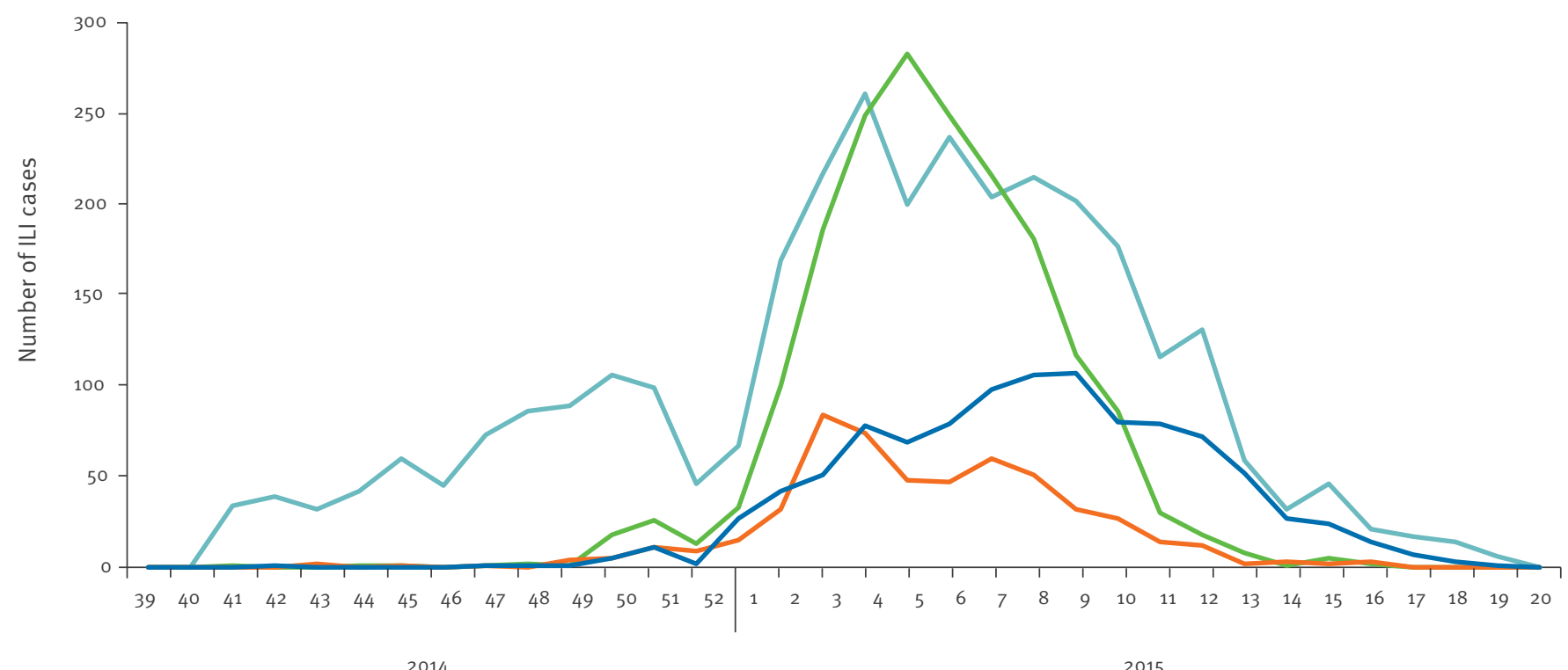

ISO week of onset of symptoms

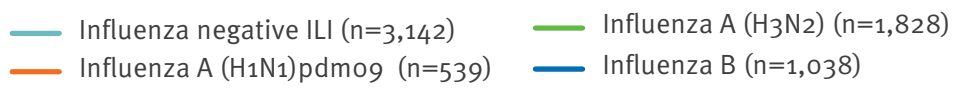

ILI: influenza-like illness; I-MOVE: Influenza Monitoring Vaccine Effectiveness in Europe, ISO: International Organization for Standardization.

a This includes 15 influenza $B+A\left(H_{3} N_{2}\right)$ co-infections and eight influenza $B+A\left(\mathrm{H}_{1} \mathrm{~N}_{1}\right)$ pdmog co-infections. Note that numbers of cases come from influenza type/subtype specific databases. Some cases are excluded due to their restriction criteria. Any influenza A non-typed cases are dropped from analysis.

The proportion vaccinated with the $2014 / 15$ influenza vaccine was $13.2 \%$ among controls, $13.0 \%$ among $\mathrm{A}\left(\mathrm{H}_{3} \mathrm{~N}_{2}\right) \mathrm{cases}, 6.9 \%$ among $\mathrm{A}\left(\mathrm{H}_{1} \mathrm{~N}_{1}\right)$ pdmog cases and $7.4 \%$ among B cases (Table 2 ).

\section{FIGURE 3}

Pooled crude and adjusted seasonal vaccine effectiveness against laboratory confirmed influenza by influenza type/subtype, and by season of vaccination, I-MOVE multicentre case-control study, Europe, influenza season 2014/15 (week 41/2014week 19/2015)

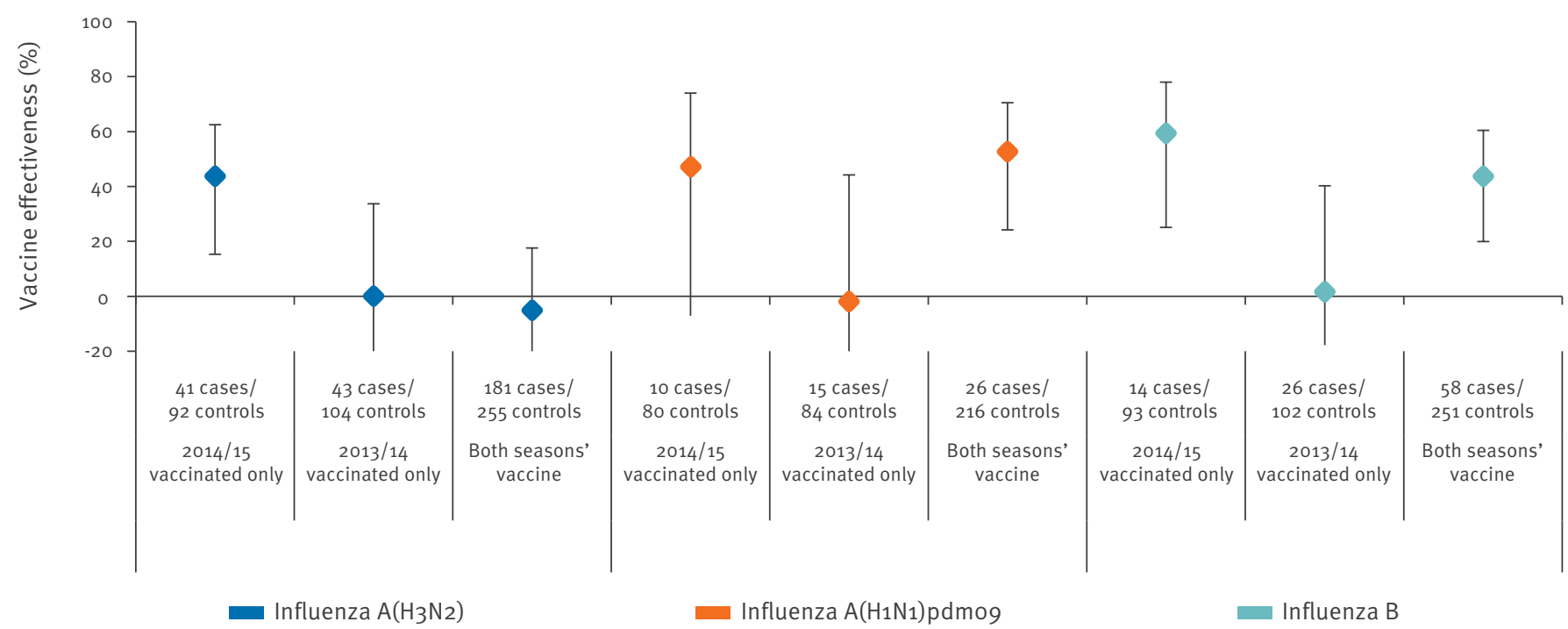

I-MOVE: Influenza Monitoring Vaccine Effectiveness in Europe. 
virus, an $\mathrm{A} /$ Texas/50/2012 ( $\left.\mathrm{H}_{3} \mathrm{~N}_{2}\right)$-like virus, and a B/ Massachusetts/2/2012-like virus [1].

In September 2014, the WHO reported the emergence of two new influenza virus genetic clades for $\mathrm{A}\left(\mathrm{H}_{3} \mathrm{~N}_{2}\right)$, clade 3 C.2a and 3 C.3a [1]. These clades had first circulated in Europe during the 2013/14 influenza season [2].

In December 2014, the United States (US) Centers for Disease Control and Prevention (CDC) issued a Health Alert reporting that $52 \%$ of the $\mathrm{A}\left(\mathrm{H}_{3} \mathrm{~N}_{2}\right)$ viruses circulating were antigenically different from the $A\left(\mathrm{H}_{3} \mathrm{~N}_{2}\right)$ component of the northern hemisphere 2014/15 influenza vaccine. CDC recommended the use of antiviral medications where indicated for the treatment and prevention of influenza, as an adjunct to vaccination [3]. Concordant with the reports of the drifted $\mathrm{A}\left(\mathrm{H}_{3} \mathrm{~N}_{2}\right)$ viruses, in January 2015, the US, Canada and the United Kingdom (UK) reported low influenza vaccine effectiveness (VE) against $\mathrm{A}\left(\mathrm{H}_{3} \mathrm{~N}_{2}\right)$ [4-6]. Canadian results suggested that $V E$ against influenza $A\left(\mathrm{H}_{3} \mathrm{~N}_{2}\right)$ among individuals who had been vaccinated in both 2013/14 and 2014/15 seasons was lower than among those who were only vaccinated in 2014/15 [5].

In Europe, the influenza season started later than in the US and Canada. Increased influenza activity in Europe was first reported in early January 2015, with a predominance of $A\left(\mathrm{H}_{3} \mathrm{~N}_{2}\right)$ but with influenza $A\left(\mathrm{H}_{1} \mathrm{~N}_{1}\right)$ pdmog and B circulating as well [7].

For this seventh season of the Influenza Monitoring Vaccine Effectiveness in Europe (I-MOVE) multicentre case-control study we aimed to measure the 2014/15 effectiveness of the seasonal influenza vaccine against the three co-circulating viruses by age group and by vaccine type. In addition, due to the potential implications for vaccination policy we explored the effect of previous vaccinations on the current season VE.

\section{Methods}

Eight study sites (Germany, Hungary, Ireland, Italy, Poland, Portugal, Romania and Spain) participated in the test-negative 2014/15 multicentre case-control study. The methods have been described previously [7-9] and are based on the European Centre for Disease Prevention and Control (ECDC) generic case-control study protocol [10].Briefly, participating general practitioners (GPs) interviewed and collected naso-pharyngeal specimens from all (seven study sites) or a systematic sample (in Germany) of patients consulting for influenza- like illness (ILI) aged 60 (Germany, Poland, and three regions in Spain) or 65 years old (Hungary, Ireland, Italy, Portugal, Romania and three regions in Spain) and older and from a systematic sample of ILI patients in the other age groups. In Hungary, only patients aged 18 years or over were eligible for inclusion in the study. GPs collected clinical and epidemiological information as previously described [8]. We included patients in the study who presented to the GPS more than 14 days after the start of the national vaccination campaigns and who met the European Union (EU) ILI case definition [11], were swabbed within seven days of symptom onset, and who had not received antivirals before swabbing.

Cases were ILI patients who were swabbed and tested positive for influenza virus using real-time reverse-transcription PCR (RT-PCR). Controls were ILI patients who tested negative for any influenza virus using RT-PCR. Cases and controls were not included in the influenza type/subtype-specific analyses if fewer than five type/ subtype-specific cases were reported by study site. Influenza A cases of unknown subtype were excluded from the analysis.

For each study site and for each influenza type/subtype, the study period started on the week of onset of the first influenza case recruited and ended on the week of onset of the last influenza case after which there were at least two consecutive weeks with no further influenza positive cases.

We defined a patient as vaccinated if they had received minimum one dose of 2014/15 influenza vaccine at least 15 days before ILI symptom onset. We considered all other patients unvaccinated. GPs ascertained vaccination based on vaccination records or patient's self-report.

For each study site, we compared the odds of vaccination in cases and controls calculating the odd ratio (OR). We conducted a complete case analysis excluding patients with missing values for any of the variables in the model measuring adjusted VE. We carried out a one-stage model with study site as a fixed effect. We used Cochran's Q-test and the $\mathrm{I}^{2}$ index to test the heterogeneity between study sites [12].

We used a logistic regression model to calculate VE including potential confounding factors: age (modelled as a restricted cubic spline with four knots or age group as a categorical variable depending on the analysis), sex, presence of at least one underlying chronic condition (including pregnancy and obesity where available) and date of symptom onset (modelled as a restricted cubic spline with four knots where sample size allowed).

To study the effect of $2013 / 14$ vaccination on the 2014/15 VE, we conducted a stratified analysis using four categories: individuals unvaccinated in both seasons (reference category), vaccinated in 2013/14 only, vaccinated in 2014/15 only, and those vaccinated in both seasons.

We measured VE by age group (0-14, 15-59 and $\geq 60$ years) and by type of vaccine (adjuvanted, egg-derived inactivated subunit, cell-derived inactivated subunit, egg-derived inactivated split virion). We excluded 


\section{FIGURE 4}

Phylogenetic tree I-MOVE multicentre case-control study, Europe, influenza season 2014/15 (week 41/2014-week 19/2015)

Germany
Ireland
Portugal
Romania
Spain
Reference strain
$2015 / 2016 \mathrm{NH}$ vaccine strain
$2014 / 2015 \mathrm{NH}$ vaccine strain

63 A/Lisboa/18/2015

A/Lisboa/niEVA235/2015

- A/Melilla/112/2015

A/Lisboa/20/2015

A/lreland/14852/2015

- A/Brandenburg/17/2015

A/Lisboa/niEVA28/2015

66 A_Lisboa/2/2015

A/Nordrhein-Westfalen/10/2015

_ A/lreland/11038/2015

_ A/reland/63742/2014

A/Ireland/09191/2015

A/Hong Kong/5738/2014 (3C.2a)

- A/Navarra/1141/2015

- A/lreland/02422/2015

A/lreland/09199/2015

A/Berlin/82/2014

64 - A/Niedersachsen/11/2014

Group 3C.2a

L3I, N144S, F159Y, K160, N225D, Q311H

- A/lreland/00075/2015

- A/PaisVasco/131/2015

A/Lisboa/niEVA151/2015

${ }_{85}$ A/Navarra/304/2015

A/Baleares/15037/2014

65 A/Nebraska/4/2014 (3C.2a)

A/PaisVasco/1153/2015

D225N

Group 3C.2

N145S

50 A/lasi/176658/2015

A/Norway/1903/2014 (3C. 2)

A/Hong Kong/146/2013 (3C.2)

Group 3C.3b

L157S, R261Q

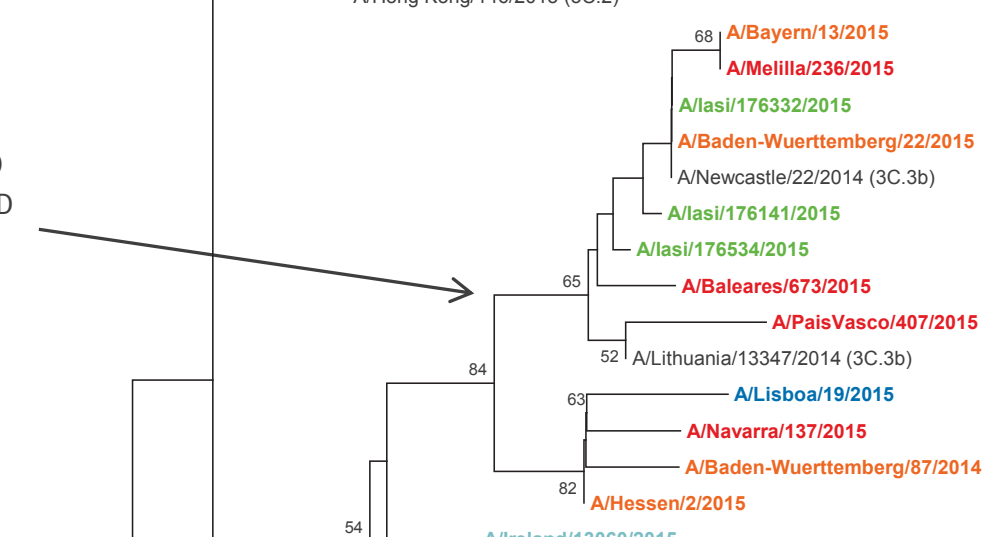

Group 3C.3

T128A, R142G

N145S

44 A/reland/13060/201

69 A/lceland/08202/2014 (3C.3)

A/Bayern/27/2015

A/Lisboa/niEVA140/2015

100 A/Lisboa/1/2015

A/Lisboa/niEVA67/2015

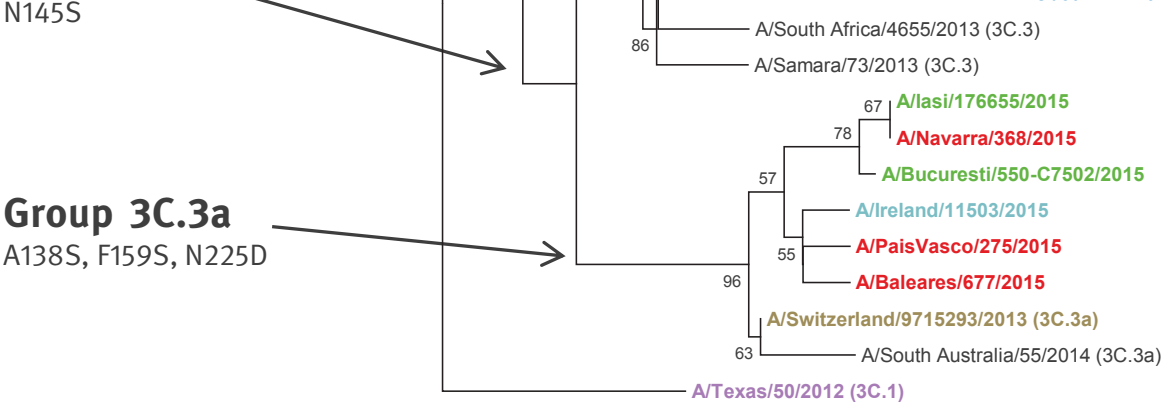

0.002 
TABLE 1 A

Details of influenza haemagglutinin sequences obtained from GISAID used in the phylogenetic analysis, I-MOVE multicentre case-control study, Europe, influenza season 2014/15 (week 41/2014-week 19/2015)

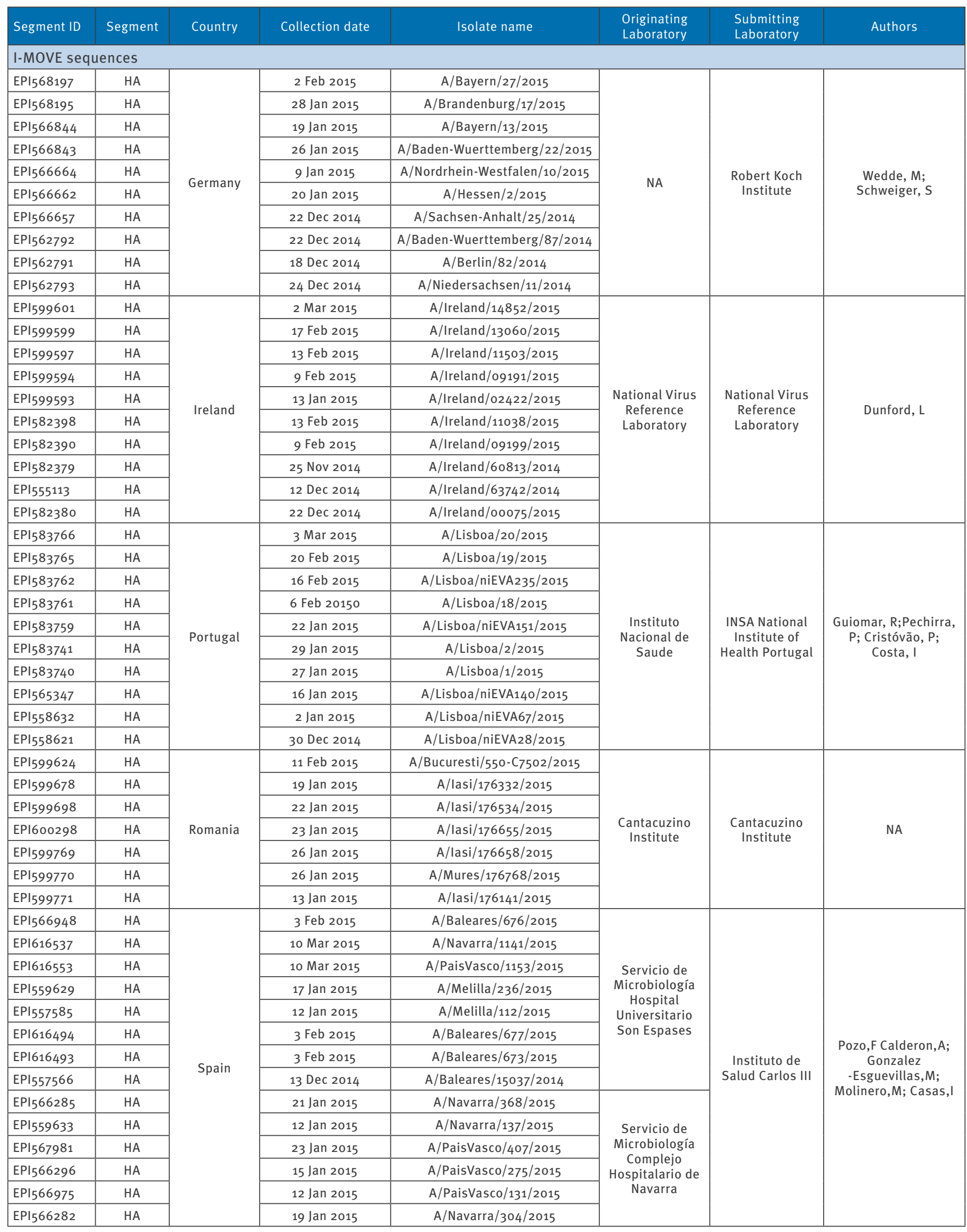

GISAID: Global Initiative on Sharing Avian Influenza Data. 
TABLE 1 B

Details of influenza haemagglutinin sequences obtained from GISAID used in the phylogenetic analysis, I-MOVE multicentre case-control study, Europe, influenza season 2014/15 (week 41/2014-week 19/2015)

\begin{tabular}{|c|c|c|c|c|c|c|c|}
\hline Segment ID & Segment & Country & Collection date & Isolate name & $\begin{array}{l}\text { Originating } \\
\text { Laboratory }\end{array}$ & $\begin{array}{l}\text { Submitting } \\
\text { Laboratory }\end{array}$ & Authors \\
\hline \multicolumn{8}{|c|}{ I-MOVE sequences } \\
\hline \multicolumn{8}{|c|}{ Reference sequences } \\
\hline EPI398417 & $\mathrm{HA}$ & United States & 15 Apr 2012 & A/Texas/50/2012 & $\begin{array}{c}\text { Texas } \\
\text { Department of } \\
\text { State Health } \\
\text { Services- } \\
\text { Laboratory } \\
\text { Services } \\
\end{array}$ & $\begin{array}{c}\text { Centers for } \\
\text { Disease Control } \\
\text { and Prevention }\end{array}$ & \multirow[t]{2}{*}{ NA } \\
\hline $\mathrm{EPI} 460558$ & $\mathrm{HA}$ & $\begin{array}{l}\text { Russian } \\
\text { Federation }\end{array}$ & 12 Mar 2013 & A/Samara/73/2013 & $\begin{array}{l}\text { WHO National } \\
\text { Influenza } \\
\text { Centre Russian } \\
\text { Federation }\end{array}$ & $\begin{array}{l}\text { National Institute } \\
\text { for Medical } \\
\text { Research }\end{array}$ & \\
\hline EPI696965 & $\mathrm{HA}$ & & 29 Jan 2015 & $\begin{array}{c}\text { A/South Australia/55/2014 } \\
(14 / 226)\end{array}$ & NA & $\begin{array}{c}\text { National Institute } \\
\text { for Biological } \\
\text { Standards and } \\
\text { Control (NIBSC) }\end{array}$ & Nicolson, $\mathrm{C}$ \\
\hline $\mathrm{EPI} 466802$ & $\mathrm{HA}$ & South Africa & 25 Jun 2013 & A/South Africa/4655/2013 & $\begin{array}{c}\text { Sandringham, } \\
\text { National } \\
\text { Institute for } \\
\text { Communicable D }\end{array}$ & \multirow{8}{*}{$\begin{array}{l}\text { National Institute } \\
\text { for Medical } \\
\text { Research }\end{array}$} & \multirow{8}{*}{ NA } \\
\hline $\mathrm{EPI}_{536340}$ & $\mathrm{HA}$ & Iceland & 10 Jun 2014 & A/Iceland/08202/2014 & $\begin{array}{l}\text { Landspitali } \\
\text { - University } \\
\text { Hospital }\end{array}$ & & \\
\hline EPI539598 & $\mathrm{HA}$ & Lithuania & 8 May 2014 & A/Lithuania/13347/2014 & $\begin{array}{l}\text { Lithuanian } \\
\text { AIDS Center } \\
\text { Laboratory }\end{array}$ & & \\
\hline $\mathrm{EPI}_{541459}$ & $\mathrm{HA}$ & Australia & 16 Jun 2014 & A/Newcastle/22/2014 & $\begin{array}{l}\text { WHO } \\
\text { Collaborating } \\
\text { Centre for } \\
\text { Reference and } \\
\text { Research on } \\
\text { Influenza }\end{array}$ & & \\
\hline $\mathrm{EPI}_{426061}$ & $\mathrm{HA}$ & $\begin{array}{l}\text { Hong Kong } \\
\text { (SAR) }\end{array}$ & 11 Jan 2013 & A/Hong Kong/146/2013 & \multirow{2}{*}{$\begin{array}{l}\text { Government } \\
\text { Virus Unit }\end{array}$} & & \\
\hline EPI539806 & $\mathrm{HA}$ & $\begin{array}{l}\text { Hong Kong } \\
\text { (SAR) }\end{array}$ & 30 Apr 2014 & A/Hong Kong/5738/2014 & & & \\
\hline $\mathrm{EPI}_{539619}$ & $\mathrm{HA}$ & United States & 11 Mar 2014 & A/Nebraska/4/2014 & $\begin{array}{c}\text { Centers for } \\
\text { Disease Control } \\
\text { and Prevention }\end{array}$ & & \\
\hline $\mathrm{EPI}_{530687}$ & $\mathrm{HA}$ & Switzerland & 6 Dec 20130 & A/Switzerland/9715293/2013 & $\begin{array}{c}\text { Hopital Cantonal } \\
\text { Universitaire de } \\
\text { Geneve }\end{array}$ & & \\
\hline
\end{tabular}

GISAID: Global Initiative on Sharing Avian Influenza Data.

study sites from the vaccine type analysis, where the given type of vaccine was not available.

We conducted four sensitivity analyses (i) restricting the study to patients swabbed less than 4 days after symptom onset, (ii) restricting to the population targeted for vaccination as defined in each country [23] (iii) excluding patients vaccinated $<15$ days after symptom onset, (iv) calculating adjusted VE using a twostage model using random effects.

The respective country's National Influenza Reference Laboratories tested swab specimens for influenza by real-time RT-PCR assays. In Spain, other laboratories participating in the National Influenza Sentinel Surveillance System tested specimens. In each study site, a non-random selection of positive specimens or isolated viruses from positive specimens were subsequently sent to the corresponding National Influenza Centre, where influenza diagnosis was confirmed and viruses characterised either by sequencing the $\mathrm{HA}_{1}$ coding portion of the haemagglutinin gene (genetic characterisation) or by haemagglutination inhibition (antigenic characterisation). The criteria to select the specimens for genetic and antigenic characterisation varied by study site.

For the I-MOVE pooled analysis, the Spanish and Portuguese National Influenza Centres analysed the nt and amino acid sequences of the $\mathrm{HA}_{1}$ coding portion of the haemagglutinin gene and used the neighbourjoining method and the Kimura 2-parameter nt substitution model for phylogenetic analysis. A phylogenetic tree was constructed with a bootstrap analysis of 500 replicates (values above 50 are shown) using MEGA software version 6 (Tamura, Stecher, Peterson, Filipski, 
and Kumar 2013). HA sequences from reference strains used in the phylogenetic analysis were obtained from the EpiFlu database of the Global Initiative on Sharing Avian Influenza Data (GISAID) (Table 1).

\section{Results}

Within the I-MOVE multicentre case-control study, the start of country-specific study periods ranged from week 41, 2014 (Germany) to week 3, 2015 (Poland), and the end from week 13, 2015 (Portugal) to week 19, 2015 (Germany). Study period duration ranged from 14 (Poland) to 31 (Germany) weeks.

Among the 7,992 ILI patients recruited, 6,579 ILI patients met the eligibility criteria including 3,142 testing negative for all influenza viruses. For the influenza type/subtype-specific analysis datasets, we included 1,828 influenza $A\left(\mathrm{H}_{3} \mathrm{~N}_{2}\right), 1,038$ influenza $B, 539$ influenza $A\left(\mathrm{H}_{1} \mathrm{~N}_{1}\right)$ pdmog (Figure 1$)$.

The median onset date was 1 February for $A\left(\mathrm{H}_{1} \mathrm{~N}_{1}\right)$ pdmo9, 1 February for $A\left(\mathrm{H}_{3} \mathrm{~N}_{2}\right)$, and 20 February for $B$ cases (Figure 2). Forty-one percent of $A\left(\mathrm{H}_{3} \mathrm{~N}_{2}\right)$ cases were recruited in Germany, $44 \%$ of $A\left(\mathrm{H}_{1} \mathrm{~N}_{1}\right)$ pdmog in Italy and $30 \%$ of B cases in Spain.

The median age was higher in influenza B cases (39 years) compared with influenza $A\left(\mathrm{H}_{3} \mathrm{~N}_{2}\right)$ and $A\left(\mathrm{H}_{1} \mathrm{~N}_{1}\right)$ cases (28 and 30 years respectively) and controls (31 years).

The proportion of patients swabbed more than three days after ILI onset was $15.9 \%$ among controls, and $10.3 \%, 13.5 \%$ and $15.9 \%$ among $\mathrm{A}\left(\mathrm{H}_{3} \mathrm{~N}_{2}\right), \mathrm{A}\left(\mathrm{H}_{1} \mathrm{~N}_{1}\right)$ pdmog and $B$ cases respectively.

The proportion of patients belonging to the target group for vaccination, or with at least one chronic condition or with at least one hospitalisation in the previous 12 months was similar between influenza $A\left(\mathrm{H}_{3} \mathrm{~N}_{2}\right)$, $\mathrm{A}\left(\mathrm{H}_{1} \mathrm{~N}_{1}\right)$ pdmo9, $\mathrm{B}$ cases and controls.

Nine percent of controls, and $11 \%, 5 \%$ and $6 \%$ of $A\left(\mathrm{H}_{3} \mathrm{~N}_{2}\right), A\left(\mathrm{H}_{1} \mathrm{~N}_{1}\right)$ pdmog and $B$ cases had received both the $2013 / 14$ and the $2014 / 15$ vaccines.

Of the 735 vaccinated individuals, 620 (84\%) had information on the vaccine type received; they were vaccinated with ten different brands. By vaccine type, $40 \%$ had received egg-derived inactivated subunit (used in all sites except in Hungary and Italy), 33\% egg-derived inactivated split virion (used in all sites except in Ireland and Romania), 21\% adjuvanted (used in Germany, Hungary, Italy and Spain) and 5\% cellderived inactivated subunit vaccines (used in Germany and Spain).

After excluding patients with missing information $(n=833 ; 7 \%)$, we included $4,491,2,920$ and 3,730 patients in the complete case analysis of VE against influenza $A\left(\mathrm{H}_{3} \mathrm{~N}_{2}\right), A\left(\mathrm{H}_{1} \mathrm{~N}_{1}\right)$ pdmog and $B$ respectively (Figure 1).

The $I^{2}$ was $<50 \%$ ( $p>0.05$ ) when assessing crude type/ subtype specific VE by study site and age group. Sample size among the $0-14$ year-olds for the $A\left(\mathrm{H}_{1} \mathrm{~N}_{1}\right)$ pdmog analysis was too small to carry out tests for heterogeneity. When assessing crude VE against $\mathrm{A}\left(\mathrm{H}_{3} \mathrm{~N}_{2}\right)$ by study site among the target group for vaccination, the $I^{2}$ was $61.5 \%(p=0.016)$.

\section{Influenza $\mathrm{A}(\mathrm{H} 3 \mathrm{~N} 2)$}

The overall adjusted VE against influenza $A\left(\mathrm{H}_{3} \mathrm{~N}_{2}\right)$ was 14.4\% (95\% Cl: -6.3 to 31.0) (Table 3).

Adjusted VE was $20.7 \%$ (95\% Cl: -22.3 to 48.5 ) among the $0-14$ year olds, $10.9 \%(95 \% \mathrm{Cl}:-30.8$ to 39.3$)$ among the $15-59$ year olds and $15.8 \%$ (95\% Cl: -20.2 to 41.0) among those $\geq 60$ years. By vaccine type, the adjusted VE point estimates were lower for cell-derived inactivated subunit vaccines (-9.3\%) compared with egg-derived inactivated subunit, egg-derived inactivated split virion, and adjuvanted vaccines (10.9\%, $18.6 \%$ and $14.0 \%$ respectively) (Table 4 ).

The adjusted VE was $43.7 \%$ ( $95 \% \mathrm{Cl}: 15.3$ to 62.5 ) among those vaccinated in $2014 / 15$ only, $0.0 \%(95 \% \mathrm{Cl}$ : -50.7 to 33.7 ) among those vaccinated in $2013 / 14$ only, and $-5.2 \%(95 \% \mathrm{Cl}:-34.3$ to 17.6$)$ among those vaccinated in both seasons (Table 4 , Figure 3 ).

The overall adjusted VE point estimate was similar to the adjusted VE among those swabbed less than 4 days of symptom onset (17.4\%) and to the adjusted VE excluding individuals vaccinated less than 15 days after symptom onset (13.7\%). The adjusted VE point estimate was higher when restricting the analysis to the target population (26.2\%) (Table 2). The adjusted VE estimates using a two-stage random effects model were similar (within $6 \%$ points) to the one-stage pooled analysis VE for all population and restricted to the target group for vaccination (Table 2). The twostage VE point estimate in the $\geq 60$ year- olds was $10 \%$ higher than the one-stage VE but three study sites were excluded from the two-stage analysis due to their limited sample size.

One hundred and fourteen (6\%) of the 1,828 A( $\left.\mathrm{H}_{3} \mathrm{~N}_{2}\right)$ viruses included in the analysis were genetically or antigenically characterised. Seventy-five viruses of the $114(66 \%)$ were antigenically distinct from the vaccine virus $A /$ Texas/50/2012: 58 belonged to clade 3C.2a, represented by $A /$ HongKong/5738/2014, and 17 belonged to clade 3 C.3a represented by $A /$ Switzerland/9715293/2013 (Table 5).

Of the 114 characterised $\mathrm{A}\left(\mathrm{H}_{3} \mathrm{~N}_{2}\right)$ viruses, 107 (94\%) were sequenced. Compared with $\mathrm{A} /$ Texas/50/2012, 17 viruses had the T128A, R142G and N145S mutations that define the group 3.C represented by $A /$ Samara/73/2013. Eight viruses had in addition the 
TABLE 2

Details for influenza, A(H3N2), A(H1N1)pdm09 and influenza B cases and controls, I-MOVE multicentre case-control study, Europe, influenza season 2014/15 (week 41/2014-week 19/2015) (n=6,524 $)$

\begin{tabular}{|c|c|c|c|c|}
\hline Variables & $\begin{array}{l}\text { Number of test-negative } \\
\text { controls / total } n(\%) \\
(n=3,142)^{b}\end{array}$ & $\begin{array}{c}\text { Number of influenza } \mathrm{A}\left(\mathrm{H}_{3} \mathrm{~N}_{2}\right) \\
\text { cases } / \text { total } n(\%) \\
(\mathrm{n}=1,828)^{\mathrm{c}}\end{array}$ & $\begin{array}{c}\text { Number of influenza } A\left(\mathrm{H}_{1} \mathrm{~N}_{1}\right) \\
\text { pdmog } / \text { total } n(\%) \\
(\mathrm{n}=1,038)^{\mathrm{d}}\end{array}$ & $\begin{array}{l}\text { Number of influenza } \\
\text { B cases / total } n(\%) \\
\qquad(n=539)^{c, d}\end{array}$ \\
\hline Median age (years) & 31.0 & 28.0 & 30.0 & 39.0 \\
\hline Missing & 5 & 1 & 1 & o \\
\hline \multicolumn{5}{|l|}{ Age groups } \\
\hline $0-4$ years & $620 / 3,137(19.8)$ & $212 / 1,827(11.6)$ & $136 / 538(25.3)$ & $62 / 1,038(6)$ \\
\hline $5-14$ years & $459 / 3,137(14.6)$ & $451 / 1,827(24.7)$ & $85 / 538(15.8)$ & 219/1,038 (21.1) \\
\hline $15-59$ years & $1,539 / 3,137(49.1)$ & $885 / 1,827(48.4)$ & $256 / 538(47.6)$ & $619 / 1,038(59.6)$ \\
\hline$\geq 60$ years & $519 / 3,137(16.5)$ & $279 / 1,827(15.3)$ & $61 / 538(11.3)$ & $138 / 1,038(13.3)$ \\
\hline Missing & 5 & 1 & 1 & 0 \\
\hline \multicolumn{5}{|l|}{ Sex } \\
\hline Female & $1,610 / 3,132(51.4)$ & $945 / 1,825(51.8)$ & $283 / 539(52.5)$ & $556 / 1,037(53.6)$ \\
\hline Missing & 10 & 3 & 0 & 1 \\
\hline \multicolumn{5}{|l|}{ Days between onset of symptoms and swabbing } \\
\hline o & $254 / 3,142(8.1)$ & $128 / 1,828(7)$ & $55 / 539(10.2)$ & $32 / 1,038(3.1)$ \\
\hline 1 & $1,076 / 3,142(34.2)$ & $662 / 1,828(36.2)$ & $206 / 539(38.2)$ & $286 / 1,038(27.6)$ \\
\hline 2 & $816 / 3,142(26)$ & $574 / 1,828(31.4)$ & $128 / 539(23.7)$ & $317 / 1,038(30.5)$ \\
\hline 3 & 497/3,142 (15.8) & $275 / 1,828(15)$ & $77 / 539(14.3)$ & $238 / 1,038(22.9)$ \\
\hline $4-7$ & 499/3,142 (15.9) & $189 / 1,828(10.3)$ & $73 / 539(13.5)$ & $165 / 1,038(15.9)$ \\
\hline Seasonal vaccination, $2014 / 15 \mathrm{e}$ & $392 / 2,978(13.2)$ & $228 / 1,759(13.0)$ & $36 / 522(6.9)$ & $75 / 1,010(7.4)$ \\
\hline Missing & 164 & 69 & 17 & 28 \\
\hline \multicolumn{5}{|l|}{ Previous season influenza vaccination } \\
\hline $\begin{array}{l}\text { Not vaccinated or vaccinated }<15 \text { days before } \\
\text { onset }\end{array}$ & $2,432 / 2,918(83.3)$ & $1,461 / 1,733(84 \cdot 3)$ & $464 / 515(90.1)$ & $901 / 1,001(90)$ \\
\hline Current season vaccination only & $98 / 2,918(3.4)$ & $41 / 1,733(2.4)$ & $10 / 515(1.9)$ & $14 / 1,001(1.4)$ \\
\hline Previous season vaccination only & $113 / 2,918(3.9)$ & $47 / 1,733(2.7)$ & $15 / 515(2.9)$ & $27 / 1,001(2.7)$ \\
\hline Current and previous season vaccination & $275 / 2,918(9.4)$ & $1,84 / 1,733(10.6)$ & $26 / 515(5.0)$ & $59 / 1,001(5.9)$ \\
\hline Missing & 224 & 95 & 24 & 37 \\
\hline \multicolumn{5}{|l|}{ 2014/15 vaccine type } \\
\hline $\begin{array}{l}\text { Not vaccinated or vaccinated < } 15 \text { days before } \\
\text { onset }\end{array}$ & $2,586 / 2,978(82.3)$ & $1,531 / 1,759(83.8)$ & $486 / 522(90.2)$ & $935 / 1,010(90.1)$ \\
\hline Egg-derived inactivated subunit & $124 / 2,978(3.9)$ & $89 / 1,759(4.9)$ & $10 / 522(1.9)$ & $27 / 1,010(2.6)$ \\
\hline Egg-derived inactivated split virion & $115 / 2,978(3.7)$ & $56 / 1,759(3.1)$ & $16 / 522(3)$ & $19 / 1,010(1.8)$ \\
\hline Adjuvanted & $81 / 2,978(2.6)$ & $38 / 1,759(2.1)$ & $3 / 522(0.6)$ & $8 / 1,010(0.8)$ \\
\hline Cell- derived inactivated subunit & $10 / 2,978(0.3)$ & $13 / 1,759(0.7)$ & $0 / 522(0)$ & $7 / 1,010(0.7)$ \\
\hline Unknown vaccine type & $62 / 2,978(2)$ & $32 / 1,759(1.8)$ & $7 / 522(1.3)$ & $14 / 1,010(1.3)$ \\
\hline Missing vaccination status or date & 164 & 69 & 17 & 28 \\
\hline At least one chronic condition & $661 / 3,024(21.9)$ & $384 / 1,776(21.6)$ & $110 / 525(21.0)$ & $216 / 1,023(21.1)$ \\
\hline Missing & 118 & 52 & 14 & 15 \\
\hline $\begin{array}{l}\text { At least one hospitalisation in the previous } 12 \\
\text { months for chronic conditions }\end{array}$ & $56 / 3,100(1.8)$ & $25 / 1,806(1.4)$ & $7 / 534(1.3)$ & $23 / 1,033(2.2)$ \\
\hline Missing & 42 & 22 & 5 & 5 \\
\hline Belongs to target group for vaccination & $902 / 3,069(29.4)$ & $511 / 1,801(28.4)$ & $141 / 530(26.6)$ & $301 / 1,029(29.3)$ \\
\hline Missing & 73 & 27 & 9 & 9 \\
\hline \multicolumn{5}{|l|}{ Study sites } \\
\hline Germany & $1,472 / 3,142(46.8)$ & $741 / 1,828(40.5)$ & $185 / 539(34.3)$ & $268 / 1,038(25.8)$ \\
\hline Ireland & $109 / 3,142(3.5)$ & $102 / 1,828(5.6)$ & $11 / 539(2)$ & $57 / 1,038(5.5)$ \\
\hline Hungary & $379 / 3,142(12.1)$ & $232 / 1,828(12.7)$ & $32 / 539(5.9)$ & $42 / 1,038(4)$ \\
\hline Portugal & $102 / 3,142(3.2)$ & $45 / 1,828(2.5)$ & $0 / 539(0)$ & $98 / 1,038(9.4)$ \\
\hline Italy & $594 / 3,142(18.9)$ & $229 / 1,828(12.5)$ & $237 / 539(44)$ & $123 / 1,038(11.8)$ \\
\hline Poland & $77 / 3,142(2.5)$ & $18 / 1,828(1)$ & $21 / 539$ (3.9) & $70 / 1,038(6.7)$ \\
\hline Romania & $76 / 3,142(2.4)$ & $80 / 1,828(4.4)$ & 43/539 (8) & $73 / 1,038(7)$ \\
\hline Spain & $333 / 3,142(10.6)$ & $381 / 1,828(20.8)$ & 10/539 (1.9) & $307 / 1,038(29.6)$ \\
\hline
\end{tabular}

I-MOVE: Influenza Monitoring Vaccine Effectiveness in Europe.

a This includes 15 influenza $B+A\left(H_{3} N_{2}\right)$ co-infections and 8 influenza $B+A\left(H_{1} N_{1}\right)$ pdmog co-infections. Note that numbers of cases come from influenza type/subtype specific databases. Some cases are excluded due to their restriction criteria. Any influenza A non-typed cases are dropped from analysis.

${ }^{b}$ Controls from 'any influenza' analysis used.

'Includes 15 influenza $B+A\left(\mathrm{H}_{3} \mathrm{~N}_{2}\right)$ co-infections.

d Includes 8 influenza $B+A\left(\mathrm{H}_{1} \mathrm{~N}_{1}\right)$ pdmog co-infections.

e Vaccination more than 14 days before onset of influenza like illness symptoms. 
TABLE 3

Pooled crude and adjusted seasonal vaccine effectiveness against laboratory-confirmed influenza by influenza type/subtype, overall and by age groups, I-MOVE multicentre case-control study, Europe, influenza season 2014/15 (week 41/2014-week $19 / 2015)$

\begin{tabular}{|c|c|c|c|c|c|c|c|c|}
\hline Type/subtype & $\begin{array}{l}\text { Analysis } \\
\text { scenario }\end{array}$ & & $\mathrm{N}^{\mathrm{a}, \mathrm{b}}$ & $\begin{array}{l}\text { Cases; vaccinated/Controls; } \\
\text { vaccinated }^{\mathrm{a}, \mathrm{b}}\end{array}$ & $\begin{array}{l}\text { Crude } \\
\text { VE }^{\mathrm{a}, \mathrm{c}}\end{array}$ & $95 \% \mathrm{Cl}$ & $\begin{array}{l}\text { Adjusted } \\
\text { VE }\end{array}$ & $95 \% \mathrm{Cl}$ \\
\hline \multirow{12}{*}{$\mathrm{A}\left(\mathrm{H}_{3} \mathrm{~N}_{2}\right)$} & \multirow{7}{*}{$\begin{array}{l}\text { 1-stage } \\
\text { pooled } \\
\text { analysis }^{d}\end{array}$} & All ages & 4,491 & 1,$723 ; 225 / 2,768 ; 365$ & -1.9 & -22.2 to 15.1 & 14.4 & -6.3 to 31.0 \\
\hline & & $0-14$ years & 1,505 & $607 ; 54 / 898 ; 64$ & -38.4 & -103.5 to 5.9 & 20.7 & -22.3 to 48.5 \\
\hline & & $15-59$ years & 2,245 & $846 ; 57 / 1,399 ; 91$ & -2.2 & -45.3 to 28.1 & 10.9 & -30.8 to 39.3 \\
\hline & & $\geq 60$ years & 741 & $270 ; 114 / 471 ; 210$ & 7.3 & -26.9 to 32.2 & 15.8 & -20.2 to 41.0 \\
\hline & & Target group for vaccination & 1,287 & $483 ; 155 / 804 ; 276$ & 10.9 & -14.5 to 30.6 & 26.2 & 1.6 to 44.7 \\
\hline & & Vaccinated $<15$ days excluded & 4,475 & 1,$718 ; 225 / 2,757 ; 365$ & -1.8 & -22.2 to 15.1 & 13.7 & -7.2 to 30.5 \\
\hline & & $\begin{array}{l}\text { Restricted delay onset and } \\
\text { swabbing } 4 \text { days }\end{array}$ & 3,869 & 1,$543 ; 196 / 2,326 ; 280$ & -10.1 & -34.4 to 9.8 & $17 \cdot 4$ & -4.6 to 34.8 \\
\hline & \multirow{5}{*}{$\begin{array}{l}\text { 2-stage } \\
\text { pooled } \\
\text { analysis }\end{array}$} & All ages & 4,503 & 1,$724 ; 225 / 2,779 ; 366$ & -0.6 & -31.2 to 22.8 & 9.0 & -28.2 to 35.4 \\
\hline & & $0-14^{\mathrm{e}}$ years & 1,418 & $564 ; 54 / 853 ; 63$ & -42.2 & -109.2 to 3.3 & 22.9 & -20.7 to 50.8 \\
\hline & & $15-59^{f}$ years & 2,192 & $853 ; 57 / 1,357 ; 88$ & -6.6 & -53.2 to 25.8 & 12.3 & -31.6 to 41.5 \\
\hline & & $\geq 60^{g}$ years & 678 & $254 ; 108 / 424 ; 187$ & 11.3 & -24.9 to 37.1 & 25.5 & -24.5 to 55.4 \\
\hline & & Target group for vaccination ${ }^{\text {h }}$ & 1,240 & $473 ; 153 / 767 ; 274$ & 6.4 & -43.2 to 38.9 & 20.7 & -32.5 to 52.5 \\
\hline \multirow{12}{*}{$\mathrm{A}\left(\mathrm{H}_{1} \mathrm{~N}_{1}\right) \mathrm{pdmog}$} & \multirow{7}{*}{$\begin{array}{l}\text { 1-stage } \\
\text { pooled } \\
\text { analysisi }\end{array}$} & All ages & 2,920 & $515 ; 36 / 2,405 ; 314$ & 53.7 & 33.1 to 68.0 & 54.2 & 31.2 to 69.6 \\
\hline & & $0-14$ years & 1,023 & $211 ; 8 / 812 ; 63$ & 59.9 & 13.4 to 81.5 & 73.1 & 39.6 to 88.1 \\
\hline & & $15-59$ years & 1,436 & $245 ; 8 / 1191 ; 75$ & 47.5 & -13.1 to 75.6 & 59.7 & 10.9 to 81.8 \\
\hline & & $\geq 60$ years & 451 & $59 ; 20 / 392 ; 171$ & 22.4 & -44.4 to 58.4 & 22.4 & -44.4 to 58.4 \\
\hline & & Target group for vaccination & 832 & $138 ; 26 / 694 ; 232$ & 53.8 & 26.0 to 71.2 & 53.6 & 22.1 to 72.3 \\
\hline & & Vaccinated $<15$ days excluded & 2,914 & $515 ; 36 / 2,399 ; 314$ & 53.9 & 33.3 to 68.1 & 54.5 & 31.6 to 69.7 \\
\hline & & $\begin{array}{l}\text { Restricted delay onset and } \\
\text { swabbing } 4 \text { days }\end{array}$ & 2,471 & $443 ; 26 / 2,028 ; 242$ & 57.8 & 35.3 to 72.5 & 61.0 & 37.7 to 75.6 \\
\hline & \multirow{5}{*}{$\begin{array}{l}\text { 2-stage } \\
\text { pooled } \\
\text { analysis }\end{array}$} & All ages & 2,650 & $494 ; 34 / 2,156 ; 285$ & 53.6 & 20.6 to 72.9 & 53.5 & 27.8 to 70.1 \\
\hline & & $0-14^{k}$ years & 916 & $196 ; 7 / 720 ; 59$ & 59.5 & -79.6 to 90.9 & 71.6 & 20.5 to 89.9 \\
\hline & & $15-59^{\prime}$ years & 941 & $195 ; 7 / 746 ; 52$ & 35.4 & -51.3 to 72.4 & 51.8 & -15.9 to 79.9 \\
\hline & & $\geq 60^{m}$ years & 290 & $41 ; 18 / 249 ; 120$ & 15.8 & -65.3 to 57.1 & NA & NA \\
\hline & & Target group for vaccination ${ }^{n}$ & 536 & $105 ; 22 / 431 ; 160$ & 53.8 & 22.3 to 72.5 & 58.4 & 10.7 to 80.6 \\
\hline \multirow{12}{*}{ Influenza B } & \multirow{7}{*}{$\begin{array}{l}\text { 1-stage } \\
\text { pooled } \\
\text { analysis }\end{array}$} & All ages & 3,730 & 1,$001 ; 74 / 2,729 ; 362$ & 47.9 & 31.3 to 60.4 & 48.0 & 28.9 to 61.9 \\
\hline & & $0-14$ years & 1,143 & $269 ; 11 / 874 ; 62$ & 37.8 & -23.2 to 68.6 & 62.1 & 14.9 to 83.1 \\
\hline & & $15-59$ years & 1,986 & $602 ; 29 / 1,384 ; 94$ & 29.6 & -10.3 to 55.0 & 41.4 & 6.2 to 63.4 \\
\hline & & $\geq 6$ oyears & 601 & $130 ; 34 / 471 ; 206$ & 54.4 & 25.8 to 72.0 & 50.4 & 14.6 to 71.2 \\
\hline & & Target group for vaccination & 1,083 & $290 ; 56 / 793 ; 273$ & 54.6 & 35.2 to 68.2 & 49.8 & 26.2 to 65.9 \\
\hline & & Vaccinated $<15$ days excluded & 3,719 & $998 ; 74 / 2,721 ; 362$ & 47.8 & 31.3 to 60.4 & 47.8 & 28.6 to 61.8 \\
\hline & & $\begin{array}{l}\text { Restricted delay onset and } \\
\text { swabbing }<4 \text { days }\end{array}$ & 3,132 & $841 ; 63 / 2,291 ; 278$ & 41.8 & 21.3 to 57.0 & 44.4 & 21.8 to 60.5 \\
\hline & \multirow{5}{*}{$\begin{array}{l}\text { 2-stage } \\
\text { pooled } \\
\text { analysis }\end{array}$} & All ages & 3,734 & 1,$003 ; 74 / 2,731 ; 363$ & 48.9 & 25.3 to 65.0 & 51.5 & 26.8 to 61.8 \\
\hline & & $0-14^{\mathrm{p}}$ years & 1,057 & $230 ; 12 / 827 ; 61$ & 29.5 & -41.3 to 64.8 & 47.5 & -15 to 76.0 \\
\hline & & $15-59$ years & 1,995 & $603 ; 29 / 1,392 ; 96$ & 28.1 & -17.1 to 55.9 & 43.2 & 5.2 to 66.0 \\
\hline & & $\geq 60^{9}$ years & 611 & $132 ; 34 / 479 ; 208$ & 53.5 & 24.1 to 71.5 & 54.1 & 22.4 to 72.8 \\
\hline & & Target group for vaccination ${ }^{r}$ & 1,057 & $293 ; 56 / 764 ; 266$ & 54.9 & 27.2 to 72.0 & 56.0 & 26.2 to 73.8 \\
\hline
\end{tabular}

CI: confidence interval; DE: Germany; ES: Spain; HU: Hungary; IE: Ireland; I-MOVE: Influenza Monitoring Vaccine Effectiveness in Europe; IT: Italy; PL: Poland; PT: Portugal; RO: Romania; VE: vaccine effectiveness.

${ }^{a}$ Based on the complete case analysis: records with missing age, sex, chronic condition, vaccination status are dropped.

${ }^{b}$ Totals may differ between one-stage and two-stage models, as adjustment at study site-level may vary to the one-stage pooled model adjustment, resulting in different missing data dropped depending on included covariates. In addition different numbers of study sites may be included in each analysis due to sample size issues.

Crude VE adjusted by study site.

${ }^{d}$ Data adjusted for age (restricted cubic spline), onset date (restricted cubic spline), sex, chronic condition and study site. Exceptions are $\mathrm{A}\left(\mathrm{H}_{3} \mathrm{~N} 2\right.$ ) all ages, where age groups $(0-4,5-14,15-59$ and $\geq 60$ years) are used instead of restricted cubic splines.

e Study sites include DE, ES, IT. HU not included in the 0-14 year old analysis, as no patients included aged «18 years. Sample size too low for IE, PT and RO.

f Study sites include DE, ES, HU, IE, IT, PT, RO. Sample size too low for PL. Crude VE for RO used in adjusted estimate, due to low sample size.

${ }^{g}$ Study sites include DE, ES, HU, IT, RO. IE, PL and PT not included due to low sample size. Crude VE for RO used in adjusted estimate, due to low sample size.

${ }^{\text {h }}$ Study sites include DE, ES, IE, IT, PL, PT, RO. HU not included in the 0-14 year old analysis, as no patients included aged <18 years.

${ }^{i}$ Data adjusted for age (restricted cubic spline), onset date (restricted cubic spline), sex, chronic condition and study site. Exceptions the A(H1N1)pdmog analysis among the elderly, where data are adjusted for age (restricted cubic spline), onset date (restricted cubic spline), and study site only.

i Study sites include DE, HU, IE, IT, RO, PL. ES and IE dropped from analysis due to small sample size.

${ }^{k}$ Study sites include DE, IT. ES, IE, PL, RO not included as sample size too low. HU not included in the 0-14 year old analysis, as no patients included aged «18 years.

' Study sites include DE, IT, RO. ES, HU, IE and PL not included as sample size too small. Crude VE for RO used in adjusted estimate, due to low sample size.

${ }^{m}$ Study sites include DE, IT. ES, HU, IE, PL and RO not included as sample size too small. Only crude VE available, due to low sample size.

${ }^{n}$ Study sites include DE, IT, RO. ES, HU, IE and PL not included as sample size too small. Crude VE for RO used in adjusted estimate, due to low sample size.

${ }^{\circ}$ Data adjusted for age (restricted cubic spline), onset date (restricted cubic spline), sex, chronic condition and study site. Exceptions the B analysis among the elderly, where data are adjusted for age (restricted cubic spline), onset date (restricted cubic spline), and study site only.

P Study sites include DE, ES, IT. IE, PL, PT and RO not included as sample size too low. HU not included in the $0-14$ year old analysis, as no patients included aged <18 years.

a Study sites include DE, ES, HU, IE, IT, PL, PT, RO. Crude VE for DE, HU, IE, PL and RO due to low sample size.

r Study sites include DE, ES, HU, IE, IT, PL, PT, RO. Crude VE for HU, IE and RO due to low sample size. 
mutations $\mathrm{G}_{5} \mathrm{E}$ and $\mathrm{N}_{31} \mathrm{~S}$. Twenty viruses belonged to the group 3C.3b represented by $A / N e w c a s t l e / 22 / 2014$ and characterised by T128A, R142G, N145S, E62K, K83R, N122D, L157S and R261Q mutations. Seven of these presented an additional amino acid change Q197H at the antigenic site B (Figure 4).

Twelve viruses belonged to the group 3 C.3a that harbours the T128A, R142G, A138S, N145S, F159S and N225D mutations. Nine of them had an extra mutation $\mathrm{K} 276 \mathrm{~N}$ at the antigenic site C. Fifty-eight viruses belonged to group $3 \mathrm{C} .2 \mathrm{a}$ and the only mutations identified were L3I, N144S, N145S, F159Y, K160T, N225D and $\mathrm{Q} 311 \mathrm{H}$ - amino acid mutations that define the group.

\section{Influenza A(H1N1)pdm09}

The overall adjusted VE against influenza $A\left(\mathrm{H}_{1} \mathrm{~N}_{1}\right)$ pdmog was $54.2 \%$ (95\% Cl: 31.2 to 69.6 ) (Table 3).The adjusted VE was $73.1 \%$ (95\% Cl: 39.6 to 88.1$)$ among the o-14 year olds, $59.7 \%(95 \% \mathrm{Cl}: 10.9$ to 81.8$)$ among the $15-59$ year olds and $22.4 \%$ ( $95 \% \mathrm{Cl}:-44.4$ to 58.4 ) among those $\geq 60$ years of age.

By vaccine type, the adjusted VE point estimate was higher for the adjuvanted vaccine (79.8\%) than for the egg-derived inactivated subunit and the inactivated split virion vaccines $(53.0 \%$ and $51.5 \%$ respectively). We could not compute the VE for the cell-derived inactivated subunit due to small numbers (7 controls vaccinated and no cases vaccinated) (Table 4 ).

The adjusted VE point estimate was lower (-1.9\%) among those vaccinated in $2013 / 14$ only compared with those vaccinated in $2014 / 15$ only $(47.2 \%)$ and to those vaccinated in both seasons (52.7\%) (Table 4 ).

The overall adjusted VE point estimate did not vary when restricting the analysis to the target group for vaccination $(53.6 \%)$, when excluding those vaccinated $<15$ days (54.5\%) before symptom onset and when using a two-stage pooled model (53.5\%). It was $61.0 \%$ when restricted to those swabbed less than 4 days of symptom onset (Table 3).

Of the $539 \mathrm{~A}\left(\mathrm{H}_{1} \mathrm{~N}_{1}\right)$ pdmog viruses, 24 (4\%) were genetically characterised and all belonged to the group $6 \mathrm{~B}$ defined by the amino acid substitutions D97N, K163Q, S185T, S203T, A256T and K283E compared with A/ California/07/2009.

\section{Influenza B}

The overall adjusted VE against influenza B was $48.0 \%$ (95\% Cl: 28.9 to 61.9 ). The adjusted VE was $62.1 \%$ (95\% Cl: 14.9 to 83.1 ) among the $0-14$ year olds, $41.4 \%$ (95\% Cl: 6.2 to 63.4 ) among the $15-59$ year olds and $50.4 \%$ (95\% Cl: 14.6 to 71.2 ) among those $\geq 60$ years old (Table 3 ).

By vaccine type, the adjusted VE point estimates were lower for cell-derived inactivated subunit vaccines $(16.0 \%)$ than for egg-derived subunit, split virion and adjuvanted vaccines $(52.4 \%, 60.1 \%, 51.9 \%$ respectively) (Table 4).

The adjusted VE point estimate was lower among those vaccinated only in $2013 / 14(1.7 \%)$ than among those vaccinated only in $2014 / 15(59.4 \%)$ or among those vaccinated in both seasons (43.8\%) (Table 4 ).

There was less than $9 \%$ absolute difference between the overall adjusted VE point estimates and the VE in all sensitivity analyses (Table 3 ). The two-stage VE point estimate in the $0-14$ years old was $15 \%$ lower than the one-stage VE point estimate but five study sites were excluded from the two-stage analysis due to their limited sample size.

Among 746 cases for which the lineage was available, 740 (99.2\%) were Yamagata and six Victoria.

One hundred and fifty-three (15\%) of the 1,038 B viruses were characterised: 151 B Yamagata and two B Victoria viruses. Of the 151 B Yamagata lineage viruses genetically characterised, 148 (98\%) belonged to $\mathrm{B} / \mathrm{Phuket} / 3073 / 2013$, clade 3 and three to $B /$ Massachusetts/02/2012. The two B Victoria viruses genetically characterised belonged to $B /$ Brisbane/60/2008 (1A).

\section{Discussion}

The results of the I-MOVE multicentre case-control study suggest a low 2014/15 influenza VE against medically attended ILI due to $\mathrm{A}\left(\mathrm{H}_{3} \mathrm{~N}_{2}\right)$ and a moderate VE against medically attended ILI due to $A\left(\mathrm{H}_{1} \mathrm{~N}_{1}\right)$ pdmog or B.

The sample size of the I-MOVE multicentre case-control study for the $2014 / 15$ season was one of the largest since 2008/09. We could estimate VE against the three circulating viruses. However, with the low influenza vaccination coverage in the participating sites, we still have limited statistical power for some subgroup analyses that provide important information for public health action like VE by previous vaccination or VE by type of vaccine. The current sample size is still too small to measure VE by vaccine product.

Measuring VE by study sites was not among the objectives of our multicentre study. In addition, as in previous seasons, study sites, sample size pending, are publishing their own results. However, even if not statistically significant, VE may differ between study sites. Differences in site-specific adjusted VE may be explained, among other factors, by variability due to the limited number of samples, unknown residual confounding, or different vaccines used. In future seasons we are confident that, with more resources, sample sizes should increase allowing for better adjustment and stratification including by vaccine brand.

Integrating virological and epidemiological information is essential to interpret VE estimates [5]. For the 
TABLE 4

Pooled crude and adjusted seasonal vaccine effectiveness against laboratory- confirmed influenza by influenza type/ subtype, by vaccine type and by influenza vaccination status in 2013/14, I-MOVE multicentre case-control study, Europe, influenza season 2014/15 (week 41/2014-week 19/2015)

\begin{tabular}{|c|c|c|c|c|c|c|c|c|}
\hline $\begin{array}{l}\text { Influenza type/ } \\
\text { subtype }\end{array}$ & & Vaccine type & N & Cases/controls & $\begin{array}{l}\text { Crude } \\
\text { VE }^{a, b}\end{array}$ & $95 \% \mathrm{Cl}$ & $\begin{array}{l}\text { Adjusted } \\
\mathrm{VE}^{\mathrm{c}}\end{array}$ & $95 \% \mathrm{Cl}$ \\
\hline \multirow{10}{*}{$\mathrm{A}\left(\mathrm{H}_{3} \mathrm{~N}_{2}\right)$} & \multirow{6}{*}{$\begin{array}{l}\text { By vaccine } \\
\text { type }\end{array}$} & Unvaccinated & 3,901 & $1,498 / 2,403$ & Ref & NA & Ref & NA \\
\hline & & $\begin{array}{l}\text { Egg-derived inactivated } \\
\text { subunit }\end{array}$ & 205 & $88 / 117$ & -5.7 & -41.7 to 21.2 & 10.9 & $\begin{array}{c}-24.3 \text { to } \\
-36.1\end{array}$ \\
\hline & & $\begin{array}{l}\text { Egg-derived inactivated split } \\
\text { virion }\end{array}$ & 164 & $56 / 108$ & -0.4 & -41.2 to 28.6 & 18.6 & -17.4 to 43.5 \\
\hline & & Adjuvanted & 116 & $38 / 78$ & 11.8 & -32.7 to 41.4 & 14.0 & -34.1 to 44.9 \\
\hline & & $\begin{array}{c}\text { Cell-Derived inactivated } \\
\text { subunit }\end{array}$ & 23 & $13 / 10$ & $-15 \cdot 3$ & $\begin{array}{c}-167.0 \text { to } \\
50.2\end{array}$ & $-9 \cdot 3$ & $\begin{array}{c}-159.1 \text { to } \\
53.9\end{array}$ \\
\hline & & Unknown & 82 & $30 / 52$ & -12.0 & -77.1 to 29.2 & 21.3 & -29.7 to 52.3 \\
\hline & \multirow{4}{*}{$\begin{array}{l}\text { By previous } \\
\text { vaccination }\end{array}$} & Unvaccinated in both seasons & 3,697 & $1,434 / 2,263$ & Ref & NA & Ref & NA \\
\hline & & Vaccinated in $2014 / 15$ only & 133 & $41 / 92$ & 29.8 & -2.7 to 52.0 & 43.7 & 15.3 to 62.5 \\
\hline & & Vaccinated in $2013 / 14$ only & 147 & $43 / 104$ & 28.2 & -3.4 to 50.2 & 0.0 & -50.7 to 33.7 \\
\hline & & Vaccinated in both seasons & 436 & $181 / 255$ & -16.4 & -43.1 to 5.3 & -5.2 & -34.3 to 17.6 \\
\hline \multirow{10}{*}{$\mathrm{A}\left(\mathrm{H}_{1} \mathrm{~N}_{1}\right) \mathrm{pdmo9}$} & \multirow{6}{*}{$\begin{array}{l}\text { By vaccine } \\
\text { type }\end{array}$} & Unvaccinated & 2,570 & $479 / 2,091$ & Ref & NA & Ref & NA \\
\hline & & $\begin{array}{l}\text { Egg-derived inactivated } \\
\text { subunit }\end{array}$ & 113 & $10 / 103$ & 47.1 & -4.5 to 73.2 & 53.0 & 4.1 to 76.9 \\
\hline & & $\begin{array}{l}\text { Egg-derived inactivated split } \\
\text { virion }\end{array}$ & 104 & $16 / 88$ & 47.5 & 8.1 to 70.0 & 51.5 & 13.4 to 72.8 \\
\hline & & Adjuvanted & 73 & $3 / 70$ & 84.4 & 49.3.to.95.2 & 79.8 & 31.o.to.94.1 \\
\hline & & $\begin{array}{l}\text { Cell-derived inactivated } \\
\text { subunit }\end{array}$ & 7 & $0 / 7$ & NA & NA & NA & NA \\
\hline & & Unknown & 53 & $7 / 46$ & 24.8 & -70.7 to 66.8 & $35 \cdot 3$ & -48.5 to 71.8 \\
\hline & \multirow{4}{*}{$\begin{array}{l}\text { By previous } \\
\text { vaccination }\end{array}$} & Unvaccinated in both seasons & 2,438 & $459 / 1,979$ & Ref & NA & Ref & NA \\
\hline & & Vaccinated in $2014 / 15$ only & 90 & $10 / 80$ & 46.6 & -5.8 to 73.0 & 47.2 & -7.1 to 74.0 \\
\hline & & Vaccinated in $2013 / 14$ only & 99 & $15 / 84$ & 11.8 & $\begin{array}{l}-56.8 \text { to } \\
50.4\end{array}$ & -1.9 & $\begin{array}{c}-86.2 \text { to } \\
44.2\end{array}$ \\
\hline & & Vaccinated in both seasons & 242 & $26 / 216$ & 53.8 & 28.9 to 69.9 & 52.7 & 24.2 to 70.5 \\
\hline \multirow{10}{*}{ B } & \multirow{6}{*}{$\begin{array}{l}\text { By vaccine } \\
\text { type }\end{array}$} & Unvaccinated & 3,294 & $927 / 2,367$ & Ref & NA & Ref & $\mathrm{NA}$ \\
\hline & & $\begin{array}{l}\text { Egg-derived inactivated } \\
\text { subunit }\end{array}$ & 146 & $27 / 119$ & $49 \cdot 3$ & 20.7 to 67.6 & 52.4 & 22.9 to 70.6 \\
\hline & & $\begin{array}{l}\text { Egg-derived Inactivated split } \\
\text { virion }\end{array}$ & 119 & $18 / 101$ & $59 \cdot 5$ & 30.8 to 76.3 & 60.1 & 30.1 to 77.3 \\
\hline & & Adjuvanted & 86 & $8 / 78$ & 51.3 & -4.1 to 77.2 & 51.9 & -6.2 to 78.2 \\
\hline & & $\begin{array}{c}\text { Cell-derived Inactivated } \\
\text { subunit }\end{array}$ & 17 & $7 / 10$ & 22.5 & $\begin{array}{c}-108.0 \text { to } \\
71.1 \\
\end{array}$ & 16.0 & $\begin{array}{c}-129.9 \text { to } \\
69.3 \\
\end{array}$ \\
\hline & & Unknown & 68 & $14 / 54$ & 25.0 & -40.7 to 60.0 & 27.3 & -40.2 to 62.3 \\
\hline & \multirow{4}{*}{$\begin{array}{l}\text { By previous } \\
\text { vaccination }\end{array}$} & Unvaccinated in both seasons & 3,127 & $894 / 2,233$ & Ref & NA & Ref & NA \\
\hline & & Vaccinated in $2014 / 15$ only & 107 & $14 / 93$ & 61.1 & 29.8 to 78.4 & 59.4 & 25.1 to -78.0 \\
\hline & & Vaccinated in $2013 / 14$ only & 128 & $26 / 102$ & 20.3 & $\begin{array}{c}-26.6 \text { to } \\
49.8\end{array}$ & 1.7 & -61.8 to 40.3 \\
\hline & & Vaccinated in both seasons & 309 & $58 / 251$ & 43.3 & 22.5 to 58.6 & 43.8 & 20.0 to 60.5 \\
\hline
\end{tabular}

CI: confidence interval; Ref: reference; I-MOVE: Influenza Monitoring Vaccine Effectiveness in Europe; NA: not applicable; VE: vaccine effectiveness.

a Based on the complete case analysis: records with missing age, sex, chronic condition, vaccination status are dropped).

${ }^{\mathrm{b}}$ Crude VE adjusted by study site.

' Data adjusted for age (restricted cubic spline or age group), onset date (restricted cubic spline), sex, chronic condition and study site.

Note: Egg-derived inactivated subunit vaccines used in DE, IE, PO, PT, RO, ES.

Egg-derived inactivated Split virion vaccines used in DE, HU, IT, PO, PT, ES.

Adjuvanted vaccines used in DE, HU, IT, ES.

Cell-derived inactivated subunit vaccines used in Germany, ES. 
TABLE 5

Influenza A(H3N2), A(H1N1)pdm09, B Yamagata, B Victoria viruses characterised by clade and study site, I-MOVE multicentre case-control study, Europe, influenza season 2014/15 (week 41/2014-week 19/2015) (n=291)

\begin{tabular}{|c|c|c|c|c|c|c|c|c|}
\hline Characterised viruses & Clade & $\begin{array}{c}\text { Germany } \\
\mathrm{N}\end{array}$ & $\begin{array}{c}\text { Hungary } \\
\mathrm{N}\end{array}$ & $\begin{array}{l}\text { Ireland } \\
\mathrm{N}\end{array}$ & $\begin{array}{c}\text { Portugal } \\
\mathrm{N}\end{array}$ & $\underset{\mathrm{N}}{\text { Romania }}$ & $\begin{array}{c}\text { Spain } \\
\mathrm{N}\end{array}$ & $\begin{array}{l}\text { Total } \\
(\%)\end{array}$ \\
\hline \multicolumn{9}{|l|}{$\mathrm{A}\left(\mathrm{H}_{3} \mathrm{~N}_{2}\right)(\mathrm{n}=114)$} \\
\hline A/HongKong/5738/2014 & $3 \mathrm{C} .2 \mathrm{a}$ & 12 & NA & 11 & 14 & 2 & 19 & $58(51)$ \\
\hline A/Switzerland/9715293/2013 & 3C.3a & NA & NA & 1 & NA & 11 & 5 & $17(15)$ \\
\hline A/Samara/73/2013 & $3 \mathrm{C} \cdot 3$ & 5 & NA & 3 & 4 & 3 & 4 & $19(17)$ \\
\hline A/Newcastle/22/2014 & $3 \mathrm{C} .3 \mathrm{~b}$ & 5 & 2 & 1 & NA & 3 & 9 & $20(17)$ \\
\hline Total A(H3 $\left.\mathrm{N}_{2}\right)$ & NA & 22 & 2 & 16 & 18 & 19 & 37 & $114(100)$ \\
\hline \multicolumn{9}{|l|}{$\mathrm{A}(\mathrm{H} 1 \mathrm{~N} 1) \mathrm{pdmog}(\mathrm{n}=24)$} \\
\hline A/SouthAfrica/3626/2013 & $6 \mathrm{~B}$ & 12 & NA & 5 & 2 & 5 & NA & $24(100)$ \\
\hline \multicolumn{9}{|l|}{ B Yamagata $(n=151)$} \\
\hline B/Phuket/3073/2013 & Clade 3 & 31 & NA & 5 & 56 & 28 & 28 & $148(98)$ \\
\hline B/Massachusetts/02/2012 & Clade 2 & NA & NA & NA & 1 & 2 & NA & $3(2)$ \\
\hline Total B Yamagata & NA & 31 & NA & 5 & 57 & 30 & 28 & $151(100)$ \\
\hline \multicolumn{9}{|l|}{ B Victoria $(n=2)$} \\
\hline B/Brisbane/60/2008 & NA & NA & NA & 2 & NA & NA & NA & $2(100)$ \\
\hline
\end{tabular}

NA: not applicable.

last two seasons, the I-MOVE multicentre case-control teams have made an effort to include genetic and antigenic results from a sample of the cases included in the study. However, the proportion of strains genetically and antigenically characterised (8.5\%) is still low, and varied by site. Two study sites (Italy, Poland) could not provide results and some sites with a low number of cases characterised a higher proportion of viruses than sites with high number of cases. For instance, 11 of the 17 clade 3 C.3a viruses characterised were from Romania, a site that contributed to only $4.4 \%$ of the $\mathrm{A}\left(\mathrm{H}_{3} \mathrm{~N}_{2}\right)$ cases. In addition, the viruses characterised were selected according to virological surveillance objectives (e.g. selection of viruses from more severe cases, from vaccinated cases, etc.). Due to the non-random selection and the different proportion of viruses characterised we cannot exclude that the viruses characterised may not be representative of the viruses from cases included in the study. For the 2015/16 season, the I-MOVE multicentre case-control study will pilot a selection procedure aiming to provide a representative sample of viruses characterised. If resources are available, the number of viruses characterised should increase.

The VE against influenza $A\left(\mathrm{H}_{3} \mathrm{~N}_{2}\right)$ was low overall, by age group and among the target group for vaccination. Four different genetic clades of $\mathrm{A}\left(\mathrm{H}_{3} \mathrm{~N}_{2}\right)$ viruses ( $3 \mathrm{C} .2 \mathrm{a}$, 3 C.3a, 3 C.3 and 3 C.3b) circulated in the eight countries participating in I-MOVE. The low VE are in concordance with the high proportion (66\%) of $3 \mathrm{C} .2 \mathrm{a}$ and $3 \mathrm{C} .3 \mathrm{a}$ drifted viruses identified among those genetically characterised. Additional mutations were detected in the $3 \mathrm{C} .3$ and $3 \mathrm{C} .3 \mathrm{~b}$ influenza $\mathrm{A}\left(\mathrm{H}_{3} \mathrm{~N}_{2}\right)$ viruses characterised but those are considered antigenically similar to the vaccine virus [13]. This season, estimates are similar to the $V E$ against $A\left(\mathrm{H}_{3} \mathrm{~N}_{2}\right)$ we observed in 2011/12 and 2013/14 [8,9]. They are lower than the final 2014/15 VE against $A\left(H_{3} N_{2}\right)$ reported in the UK even if the proportion of drifted virus among those genetically characterised are higher in UK than in our study [14]. VE against $A\left(\mathrm{H}_{3} \mathrm{~N}_{2}\right)$ was below $20 \%$ for all vaccine types with a lower point estimate for the cell-derived subunit vaccine. The effectiveness was lower in those vaccinated in both $2013 / 14$ and $2014 / 15$ than in those vaccinated only in the $2014 / 15$ season. These observations are in line with the results of the 2014/15 early $\mathrm{A}\left(\mathrm{H}_{3} \mathrm{~N}_{2}\right) \mathrm{VE}$ estimates in Canada [5] and with those observed in previous studies [15-17]. They are congruent with the hypothesis that prior immunisation may decrease the effectiveness of the vaccine and that this negative interference is more important when the antigenic distance is small between successive vaccine components but large between vaccine and circulating strain [18]. These conditions were present in 2014/15 with an unchanged $\mathrm{A}\left(\mathrm{H}_{3} \mathrm{~N}_{2}\right)$ vaccine component compared with the 2013/14 vaccine and with a mismatch between the vaccine and a high proportion of circulating strains. However, those results may be due to chance, or to bias. We need a much larger sample size to have higher precision in the estimates and to study the effect of prior vaccinations by age group. In our study, individuals vaccinated in both seasons are older than those vaccinated only in one season (median age 63 years and 50 years respectively). Unmeasured differences between individuals vaccinated in two consecutive seasons and those vaccinated only in one season may have affected the results. Previous vaccination was documented through GP records or patient self-reports and may be subject to error. Since neither the ILI patient nor the GPs knew if the patient was an influenza case we are confident that differential recall 
did not bias the results. If the results were not due to bias or to chance, concurrent immunological studies will be essential to better understand the biological mechanism behind, and the role of natural vs vaccineacquired immunity.

The VE estimates against influenza $\mathrm{A}\left(\mathrm{H}_{1} \mathrm{~N}_{1}\right)$ pdmog are similar to our results in previous seasons [7-9]. The laboratory results indicate that the strains isolated from study participants were similar to the $A\left(\mathrm{H}_{1} \mathrm{~N}_{1}\right)$ pdmog component of the 2014/15 influenza vaccine. As in 2013/14, we observed a lower VE among the elderly and higher among those aged 0-14 years old, however sample sizes were small in the age group analyses. The VE point estimates of the adjuvanted vaccines were higher but the small sample size in the analysis does not allow a comparison of effectiveness between vaccine types.

The VE against influenza B ranged from $41 \%$ to $62 \%$ in the overall population and was $56 \%$ in the target group for vaccination. Our estimates are similar to those reported by the UK [14]. Nearly all viruses (99\%) for which lineage was available were B/Yamagata and $98 \%$ of those characterised belonged to clade 3 that is antigenically similar to the vaccine virus. VE was similar by vaccine type with lower point estimate for cellderived inactivated subunit vaccines but the sample size is too low to interpret this observed difference. The results suggested no effect of the 2013/14 vaccine and a slightly lower VE among those vaccinated in both seasons.

This is the third season we provide VE by vaccine type. A high proportion of vaccinated study participants $(84 \%)$ had vaccine product documented. Even with one of the largest sample size since 2008/09, the numbers are still too low to measure adjusted VE by vaccine type and age group. The European Medicines Agency (EMA) requests that vaccine producers provide product-specific vaccine effectiveness [19]. Taking into account the high number of vaccine products and the low vaccination coverage in countries participating in the study [20] the sample size to measure VE by vaccine product with high precision has to be much larger and substantial additional resources are needed. In a survey among I-MOVE partners to assess the feasibility of conducting product-specific VE in Europe (data not shown) most experts considered that in terms of resources allocation, providing precise estimates early in the season, by age group, by previous vaccination were of higher priority than measuring VE by product.

In summary, the 2014/15 results suggest a moderate effectiveness against influenza $\mathrm{A}\left(\mathrm{H}_{1} \mathrm{~N}_{1}\right)$ pdmog and $\mathrm{B}$. The low effectiveness of the influenza vaccines against $A\left(H_{3} \mathrm{~N}_{2}\right)$ observed again this season underlines the need to improve the $A\left(\mathrm{H}_{3} \mathrm{~N}_{2}\right)$ component of the vaccine especially among the target group for vaccination. This would be even more important if the observed negative effect of previous vaccination was confirmed. Since
$A\left(\mathrm{H}_{3} \mathrm{~N}_{2}\right)$ virus is generally associated with more severe disease in the elderly and high-risk groups [21,22] and the vaccine is less effective against this influenza subtype, in seasons of $A\left(\mathrm{H}_{3} \mathrm{~N}_{2}\right)$ circulation early antiviral treatment should be recommended in these groups $[3,6]$.

The effect of previous vaccinations is one of the questions that I-MOVE and other influenza VE teams in the US, Canada and Australia started to raise some years ago $[17,24-27]$. This is an important issue that may impact vaccination policy in Europe. They need to be addressed through international collaboration, a multidisciplinary approach and with long-term scientific independent studies. The I-MOVE multicentre casecontrol study should continue to increase the sample size and to strengthen the virological component of the study to contribute to answer these questions.

\section{I-MOVE multicentre case-control team}

Authors included in the I-MOVE multicentre case-control team (in addition to the 18 listed before and in alphabetical order of countries)

- Germany:

Silke Buda, Department for Infectious Disease Epidemiology Respiratory Infections Unit Robert Koch Institute, Berlin.

Kerstin Prahm, Department for Infectious Disease Epidemiology Respiratory Infections Unit

Robert Koch Institute, Berlin.

Brunhilde Schweiger, Reference Centre for Influenza, Robert Koch Institute, Berlin.

Marianne Wedde, National Reference Centre for Influenza, Robert Koch Institute, Berlin.

Barbara Biere, Robert Koch Institute, Berlin.

- Hungary:

Beatrix Oroszi, Department of Public Health, Strategic Planning and Epidemiology, Office of the Chief Medical Officer, Budapest.

Éva Herczegh, Influenza Virus Laboratory, National Center for Epidemiology, Budapest.

- Ireland: Coralie Giese, EPIET, European Centre for Disease Control and Prevention, Stockholm; HSE-Health Protection Surveillance Centre, Dublin

- Italy:

Valeria Alfonsi, Istituto Superiore di Sanità, Rome.

Maria Rita Castrucci, Istituto Superiore di Sanità, Rome.

Simona Puzzeli, Istituto Superiore di Sanità, Rome.

- Portugal:

Ana Rodrigues, Department of Epidemiology, National Institute of Health Dr. Ricardo Jorge, Lisbon. 
Raquel Guiomar, Department of Infectious Diseases, National Institute of Health Dr. Ricardo Jorge, Lisbon.

Inês Costa, Department of Infectious Diseases, National Institute of Health Dr. Ricardo Jorge, Lisbon.

Paula Cristóvão, Department of Infectious Diseases, National Institute of Health Dr. Ricardo Jorge, Lisbon.

- Romania:

Emilia lupulescu, 'Cantacuzino' National Institute of Research, Bucharest.

Alina Elena Ivanciuc, 'Cantacuzino' National Institute of Research, Bucharest.

Carmen Maria Cherciu, 'Cantacuzino' National Institute of Research, Bucharest.

Maria Elena Mihai, 'Cantacuzino' National Institute of Research, Bucharest.

Cristina Tecu, 'Cantacuzino' National Institute of Research, Bucharest.

Gheorge Necula, 'Cantacuzino' National Institute of Research, Bucharest.

- Spain:

Jone Altzíbar, Dirección de Salud Pública de Gipuzkoa, Department of Health, Basque Government, San Sebastián-Donostia.

Manuel García Cenoz, Public Health Institute of Navarra, Pamplona.

Jose Lozano, Consejería de Sanidad, Dirección General de Salud Pública, Valladolid.

Eva Martínez-Ochoa, Department: Servicio de Epidemiología y Prevención Sanitaria. Dirección General de Salud Pública y Consumo de La Rioja, Logroño.

Juana Vanrell, Servicio de Epidemiología, Dirección General de Sanidad y Consumo, Illes Ballears, Palma de Mallorca.

Daniel Castrillejo, Servicio de Epidemiología, Dirección General de Sanidad y Consumo, Consejería de Bienestar Social y Sanidad, Melilla.

\section{Acknowledgements}

We acknowledge the authors, originating and submitting laboratories of the sequences from GISAID's EpiFlu Database on which this research is based. The list of sequences used is detailed in Table 1 in the text. All submitters of data may be contacted directly via the GISAID website www.gisaid.org.

WHO-EURO contributed to the funding of the study site in Romania; ECDC contributed to the funding of the study coordination and three study sites.

All study participants, all participating GPs and paediatricians from Germany, Hungary, Ireland, Italy, Poland, Portugal, Romania, and Spain.

Kari Johansen, Pasi Penttinen, European Centre for Disease Prevention and Control, Sweden.

Pernille Jorgensen, WHO-EURO, Copenhagen.

\section{- EpiConcept}

Valérie Nancey, EpiConcept, Paris.

Nathalie Colombo, EpiConcept, Paris.

Guillaume Jeannerod, EpiConcept, Paris.

Marc Rondy, EpiConcept, Paris

- Germany:

Michael Herzhoff, Robert Koch Institute, Berlin.

- Ireland

Deval Igoe, HSE-Health Protection Surveillance Centre, Dublin.

Darina O Flanagan, HSE-Health Protection Surveillance Centre, Dublin.

Kasia Piotrowska-Millane, HSE-Health Protection Surveillance Centre, Dublin.

Claire Collins, Irish College of General Practitioners, Dublin.

Michael Joyce, Irish College of General Practitioners, Dublin.

Olga Levis: Irish College of General Practitioners, Dublin.

Suzie Coughlan, National Virus Reference Laboratory, Dublin.

Allison Waters, National Virus Reference Laboratory, Dublin.

Margaret Duffy, National Virus Reference Laboratory, Dublin.

Grainne Tuite, National Virus Reference Laboratory, Dublin.

Linda Dunford, National Virus Reference Laboratory, Dublin.

Cillian De Gascun, National Virus Reference Laboratory, Dublin.

- Italy:

Regional reference laboratory for Influenza that participated in the study.

- Portugal

Baltazar Nunes, Department of Epidemiology, National Institute of Health Dr. Ricardo Jorge, Lisbon.

- Poland: Lidia Brydak, Karolina Bednarska, Ewelina HallmanSzelińska, National Influenza Center, National Institute of Public Health, National Institute of Hygiene, Warsaw; Justyna Rogalska, Epidemiology Department, National Institute of Public Health-National Institute of Hygiene, Warsaw.

\section{- Romania}

WHO-EURO funded part of the study.

Rodica Popescu and Odette Popovici, National Centre of Surveillance and Control of communicable Diseases, Bucharest.

Epidemiologists and sentinel GPs and their patients from participating districts,

Laboratory staff of NIC Cantacuzino: Luiza Ustea, Emilia Dobre, Nuti Enache and Mirela Ene. 
- Spain: Fernando Carril, Departamento de Salud, Gobierno del País Vasco, Spain; Rosa Sancho Martinez, Unidad de Vigilancia Epidemiológica de Gipuzkoa, País Vasco, Spain; Inmaculada Aspirichaga Gamarra, Unidad de Vigilancia Epidemiológica de Bizkaia, País Vasco, Spain; Larraitz Etxebarriarteun Aranzabal, Unidad de Vigilancia Epidemiológica de Álava, País Vasco, Spain; Jesús Castilla, Instituto de Salud Pública de Navarra, Spain, Tomás Vega, Consejería de Sanidad, Dirección General de Salud Pública, Valladolid, Spain; Carmen Quiñones, Servicio de Epidemiología y Prevención Sanitaria, Dirección General de Salud Pública y Consumo de La Rioja, Spain; J Giménez, Servicio de Epidemiología, Dirección General de Salut Pública, Baleares, Spain; Concha Delgado, National Centre of Epidemiology/ CIBER Epidemiología y Salud Pública (CIBERESP), Institute of Health Carlos III, Madrid; Salvador de Mateo, National Centre of Epidemiology/ CIBER Epidemiología y Salud Pública (CIBERESP), Institute of Health Carlos III; Madrid; Silvia Jiménez-Jorge, National Centre of Epidemiology/ CIBER Epidemiología y Salud Pública (CIBERESP), Institute of Health Carlos III; Madrid, Spain; Inmaculada Casas, National Centre for Microbiology, National Influenza Centre, Institute of Health Carlos III, Madrid, Spain.

\section{Conflict of interest}

None declared.

\section{Authors' contributions}

All authors provided contribution to the research article and approved the final version.

Marta Valenciano, coordinated the I-MOVE multicentre case control study network, supervised the statistical analysis and interpretation of the results, led the writing of the research article.

Esther Kissling was responsible for the data management of the multicentre study, undertook the statistical analysis on which the research article is based, contributed to the writing of the research article

Marta Valenciano, Esther Kissling and Alain Moren were involved in the original methodological design

Annicka Reuss, Caterina Rizzo, Alin Gherasim, Judit Krisztina Horváth, Lisa Domegan, Daniela Pitigoi, Ausenda Machado, Iwona Anna Paradowska-Stankiewicz, Antonino Bella, Amparo Larrauri, Annamária Ferenczi, Joan 0`Donell, Mihaela Lazar, Ausenda Machado, Monika Roberta Korczyńska, coordinated the corresponding national component of the I-MOVE study, contributed to the conception, design, acquisition and interpretation of the data.

Pedro Pechirra contributed in Portugal to the acquisition and laboratory diagnosis data analisys and performed genetic analysis. He built the phylogenetic tree for the multicentre case-control study.

Francisco Pozo coordinated the virological aspects of the Spanish study and was responsible of compiling, summarising and interpreting the virological data from sites participating in the multicentre case-control study.

Alain Moren contributed to the writing of the research article and supervised the statistical analysis and interpretation of the results.

- Germany:
Silke Buda was responsible for the coordination of data acquisition and interpretation of results-

Kerstin Prahm was responsible for acquisition and validation of data.

Brunhilde Schweiger was responsible for the coordination of data acquisition and interpretation of virological results.

Marianne Wedde was responsible for analysis and interpretation of virological results.

Barbara Biere was responsible for analysis and interpretation of virological results.

\section{- Hungary}

Beatriz Oroszi substantially contributed to substantia to conception and design, acquisition of data, or analysis and interpretation of data.

Eva Herczegh was responsible of acquisition and interpretation of data.

- Ireland

Coralie Giese contributed to the data analysis and interpretation of data.

- Italy

Valeria Alfonsi contributed to the acquisition and interpretation of the data.

Maria Rita Castrucci and Simona Puzelli coordinated the virological surveillance at National level.

- Portugal

Ana Rodrigues contributed to the acquisition and interpretation of the data.

Raquel Guiomar contributed to the design acquisition and laboratory diagnosis and data analysis.

Inês Costa and Paula Cristóvão performed laboratory diagnosis and data analysis.

\section{- Romania}

Emilia Lupulescu revised the study protocol, coordinated the laboratory diagnosis.

Alina Elena Ivanciuc was responsible for molecular detection. Carmen María Cherciu was responsible of virus isolation and antigenic characterisation.

Maria Elena Mihai was responsible of antiviral sensitivity.

Cristina Tecu was responsible of virus isolation.

Gheorge Necula was responsible of virus genetic characterisation.

- Spain

Jone Altzíbar, Manuel García Cenoz, Jose Lozano, Eva Martínez-Ochoa, Juana Vanrell, Daniel Castrillejo, have contributed to the acquisition and interpretation of data. 
1. World Health Organization (WHO). Recommended composition of influenza virus vaccines for use in the 2014-2015 southern hemisphere influenza season [Internet]. WHO: Geneva; 2014 Sep. Available from: http://www.who.int/influenza/vaccines/ virus/recommendations/201409_recommendation.pdf?ua=1

2. National Institute for Medical Research. WHO Influenza Centre London. Report prepared for the WHO annual consultation on the composition of influenza vaccine for the Southern Hemisphere 2015. 22 - 24 September 2014. [Internet]. 2014. Available from: https://www.crick.ac.uk/media/221823/nimrvcm-report-sep-14-web.pdf

3. Centers for Disease Prevention and Control (CDC), CDC Health Advisory Regarding the Potential for Circulation of Drifted Influenza A (H3 $\left.\mathrm{N}_{2}\right)$ Viruses. 2014 Dec 3; Available from: http:// emergency.cdc.gov/HAN/hanoo374.asp

4. Centers for Disease Control and Prevention,Flannery B, Clippard J, Zimmerman RK, Nowalk MP, Jackson ML, Jackson $\mathrm{LA}$, et al. . Early estimates of seasonal influenza vaccine effectiveness - United States, January 2015.MMWR Morb Mortal Wkly Rep. 2015;64(1):10-5.PMID: 25590680

5. Skowronski DM, Chambers C, Sabaiduc S, De Serres G, Dickinson JA, Winter AL, et al. Interim estimates of 2014/15 vaccine effectiveness against influenza $A\left(\mathrm{H}_{3} \mathrm{~N}_{2}\right)$ from Canada's Sentinel Physician Surveillance Network, January 2015. Euro Surveill. 2015;20(4):21022. DOI: 10.2807/1560-7917. ES2015.20.4.21022 PMID: 25655053

6. Pebody RG, Warburton F, Ellis J, Andrews N, Thompson $C$, von Wissmann $B$, et al. Low effectiveness of seasonal influenza vaccine in preventing laboratory-confirmed influenza in primary care in the United Kingdom: 2014/15 mid-season results. Euro Surveill. 2015;20(5):21025. . Available from: http://www.eurosurveillance.org/ ViewArticle.aspx?Articleld=21025DOI: 10.2807/1560-7917. ES2015.20.5.21025 PMID: 25677050

7. Kissling E, Valenciano M, Buchholz U, Larrauri A, Cohen JM, Nunes B, et al. Influenza vaccine effectiveness estimates in Europe in a season with three influenza type/subtypes circulating: the I-MOVE multicentre case-control study, influenza season 2012/13. Euro Surveill. 2014;19(6):20701. DOI: $10.2807 / 1560-7917 . E S 2014 \cdot 19 \cdot 6.20701$ PMID: 24556348

8. I-MOVE Multicentre Case Control Study Team,Valenciano M, Kissling E, Reuss A, Jiménez-Jorge S, Horváth JK, Donnell JMO, et al. . The European I-MOVE Multicentre 2013-2014 CaseControl Study. Homogeneous moderate influenza vaccine effectiveness against $\mathrm{A}\left(\mathrm{H}_{1} \mathrm{~N}_{1}\right)$ pdmog and heterogenous results by country against $A\left(\mathrm{H}_{3} \mathrm{~N}_{2}\right)$.Vaccine. 2015;33(24):2813-22. DOI: 10.1016/j.vaccine.2015.04.012 PMID: 25936723

9. Kissling E, Valenciano M, Larrauri A, Oroszi B, Cohen JM, Nunes $B$, et al. Low and decreasing vaccine effectiveness against influenza $\mathrm{A}\left(\mathrm{H}_{3}\right)$ in $2011 / 12$ among vaccination target groups in Europe: results from the I-MOVE multicentre casecontrol study. Euro Surveill. 2013;18(5):20390.PMID: 23399425

10. European Centre for Disease Prevention and Control (ECDC). Protocol for case control studies to measure pandemic and seasonal vaccine effectiveness in the European Union and European Economic Area [Internet]. Stockholm: ECDC; 2010. Available from:_http://www.ecdc.europa.eu/en/publications/ Publications/0907_TED_Influenza_AH1N1_Measuring_ Influenza_Vaccine_Effectiveness_Protocol_Case_Control Studies.pdf_

11. European Commission. Commission Decision 2009/363/EC of 30 April 2009 amending Decision 2002/253/EC laying down case definitions for reporting communicable diseases to the Community network under Decision No 2119/98/EC of the European Parliament and of the Council. [Internet]. 2009 Jan p. 58. Report No.: OJ L 110. Available from: http://eur-lex.europa. eu/LexUriServ/LexUriServ.do?uri=0J:L:2009:110:0058:0059:E $\mathrm{N}: \mathrm{PDF}$

12. Huedo-Medina TB, Sanchez-Meca J, Marin-Martinez F, Botella J. Assessing heterogeneity in meta-analysis: $Q$ statistic or 12 index? PsycholMethods. 2006 Jun;11(1082-989X (Print)):193-206.

13. European Centre for Disease Prevention and Control. Influenza virus characterisation, summary Europe, June 2015 [Internet]. Stockholm: ECDC; 2015. Available from: http://ecdc.europa.eu/ en/publications/Publications/influenza-virus-characterisationJune-2015.pdf

14. Pebody R, Warburton F, Andrews N, Ellis J, von Wissmann B Robertson C, et al. Effectiveness of seasonal influenza vaccine in preventing laboratory-confirmed influenza in primary care in the United Kingdom: 2014/15 end of season results. Euro Surveill. 2015;20(36):30013. . Available from: http://www. eurosurveillance.org/images/dynamic/EE/V20N36/art21237. pdfDOI: $10.2807 / 1560-7917 . E S .2015 \cdot 20.36 .30013$ PMID: 26535911

15. Ohmit SE, Petrie JG, Malosh RE, Cowling BJ, Thompson MG, Shay DK, et al. Influenza Vaccine Effectiveness in the
Community and the Household. Clin Infect Dis [Internet]. 2013 May 15 [cited 2015 Aug 11];56(10):1363-9. Available from: http://cid.oxfordjournals.org/lookup/doi/10.1093/cid/cito6o

16. Pebody R, Andrews N, McMenamin J, Durnall H, Ellis J, Thompson $\mathrm{Cl}$, et al. Vaccine effectiveness of $2011 / 12$ trivalent seasonal influenza vaccine in preventing laboratoryconfirmed influenza in primary care in the United Kingdom: evidence of waning intra-seasonal protection. Euro Surveill. 2013;18(5):20389.PMID: 23399424

17. Skowronski DM, Janjua NZ, De Serres G, Sabaiduc S, Eshaghi A, Dickinson JA, et al. Low 2012-13 Influenza Vaccine Effectiveness Associated with Mutation in the Egg-Adapted $\mathrm{H}_{3} \mathrm{~N}_{2}$ Vaccine Strain Not Antigenic Drift in Circulating Viruses. Kobinger GP, editor. PLoS ONE. 2014 Mar 25;9(3):e92153. Available from: http://dx.plos.org/10.1371/journal. pone.0092153

18. Smith DJ. Mapping the Antigenic and Genetic Evolution of Influenza Virus. Science [Internet]. 2004 Jul 16 [cited 2013 May 14];305(5682):371-6. Available from: http://www.sciencemag. org/cgi/doi/10.1126/science.1097211

19. European Medicine Agency. Explanatory note on the withdrawal of the Note for guidance on harmonisation of requirements for influenza Vaccines and of the core SmPC/PL for inactivated seasonal influenza vaccines. Jan 22, 2014.

20. European Centre for Disease Prevention and Control (ECDC). Seasonal influenza vaccination in Europe- Overview of vaccination recommendations and coverage rates in the $\mathrm{EU}$ Member States for the 2012-13 influenza season. Stockholm: ECDC; 2015 Jan.

21. Kaji M, Watanabe A, Aizawa H. Differences in clinical features between influenza $A \mathrm{H}_{1} \mathrm{~N}_{1}, A \mathrm{H}_{3} \mathrm{~N}_{2}$, and $B$ in adult patients. Respirology. 2003;8(2):231-3. . Available from: http://doi.wiley. com/10.1046/j.1440-1843.2003.00457.xDOI: $10.1046 / j .1440-$ 1843.2003.00457.x PMID: 12753540

22. Lee BE, Mukhi SN, Drews SJ. Association between patient age and influenza A subtype during influenza outbreaks. Infect Control Hosp Epidemiol. 2010;31(5):535-7. . Available from: http://www.jstor.org/stable/10.1086/652159DOI: 10.1086/652159 PMID: 20334548

23. European Centre for Disease Prevention and Control (ECDC). Seasonal influenza vaccines. Stockholm: ECDC; 2016. Available from: http://ecdc.europa.eu/en/healthtopics/seasonal_ influenza/vaccines/Pages/vaccines.aspx

24. Simpson CR, Lone NI, Kavanagh K, Ritchie LD, Robertson C, Sheikh A, et al. Trivalent inactivated seasonal influenza vaccine effectiveness for the prevention of laboratoryconfirmed influenza in a Scottish population 2000 to 2009. Euro Surveill. 2015;20(8):21043. DOI: 10.2807/1560-7917. ES2015.20.8.21043 PMID: 25742433

25. Ohmit SE, Thompson MG, Petrie JG, Thaker SN, Jackson ML, Belongia EA, et al. Influenza vaccine effectiveness in the 2011-2012 season: protection against each circulating virus and the effect of prior vaccination on estimates. Clin Infect Dis. 2014;58(3):319-27. DOI: 10.1093/cid/cit736 PMID: 24235265

26. McLean HQ, Thompson MG, Sundaram ME, Meece JK, McClure $\mathrm{DL}$, Friedrich TC, et al. Impact of repeated vaccination on vaccine effectiveness against influenza $A\left(G_{3} N_{2}\right)$ and $B$ during 8 seasons.Clin Infect Dis. 2014 Nov 15;59(10):1375-85. doi: 10.1093/cid/ciu680. Epub 2014 Sep 29

27. Sullivan SG, Kelly H. Stratified estimates of influenza vaccine effectiveness by prior vaccination: caution required.Clin Infect Dis. 2013;57(3):474-6. DOI: 10.1093/cid/cit255 PMID: 23619811

\section{License and copyright}

This is an open-access article distributed under the terms of the Creative Commons Attribution (CC BY 4.0) Licence. You may share and adapt the material, but must give appropriate credit to the source, provide a link to the licence, and indicate if changes were made.

This article is copyright of the authors, 2016. 